\title{
International consensus guidelines for scoring the histopathological growth patterns of liver metastasis
}

Pieter-Jan van Dam ${ }^{1}$, Eric P van der Stok ${ }^{2}$, Laure-Anne Teuwen ${ }^{1}$, Gert G Van den Eynden ${ }^{1}$, Martin Illemann ${ }^{3}$, Sophia Frentzas ${ }^{4}$, Ali W Majeed ${ }^{5}$, Rikke L Eefsen ${ }^{6}$, Robert RJ Coebergh van den Braak ${ }^{2}$, Anthoula Lazaris ${ }^{7}$, Maria Celia Fernandez ${ }^{8}$, Boris Galjart ${ }^{2}$, Ole Didrik Laerum ${ }^{9}$, Roni Rayes ${ }^{8}$, Dirk J Grünhagen ${ }^{2}$, Michelle Van de paer ${ }^{1,10}$, Yves Sucaet ${ }^{11,12}$, Hardeep Singh Mudhar ${ }^{13}$, Michael Schvimer ${ }^{14}$, Hanna Nyström ${ }^{15}$, Mark Kockx ${ }^{10}$, Nigel C Bird ${ }^{16}$, Fernando Vidal-Vanaclocha ${ }^{17}$, Peter Metrakos ${ }^{7}$, Eve Simoneau ${ }^{7}$, Cornelis Verhoef ${ }^{2}$, Luc Y Dirix ${ }^{1}$, Steven Van Laere ${ }^{1}$, Zu-hua Gao ${ }^{18}$, Pnina Brodt ${ }^{8}$, Andrew R Reynolds ${ }^{\star}, 4,19$ and Peter B Vermeulen ${ }^{\star}, 1,4,10$

${ }^{1}$ Translational Cancer Research Unit, GZA Hospitals (St Augustinus), Wilrijk-Antwerp, Belgium; 2Department of Surgical Oncology, Erasmus MC Cancer Institute, Rotterdam, The Netherlands; ${ }^{3}$ The Finsen Laboratory, Rigshospitalet/BRIC, Faculty of Health Sciences, University of Copenhagen, Copenhagen, Denmark; ${ }^{4}$ Tumour Biology Team, Breast Cancer Now Toby Robins Research Centre, The Institute of Cancer Research, London, UK; ${ }^{5}$ Hepatobiliary Surgery, Sheffield Teaching Hospitals, Sheffield, UK; ${ }^{6}$ Department of Oncology, Naestved Hospital, Naestved, Denmark; ${ }^{7}$ Department of Surgery, Cancer Research Program, McGill University Health Centre Research Institute, Montreal, QC, Canada; ${ }^{8}$ Departments of Surgery, Oncology and Medicine, McGill University and the McGill University Health Center Research Institute, Cancer Research Program, Montreal, QC, Canada; ${ }^{9}$ The Finsen Laboratory and Department of Radiation Biology, Copenhagen University Hospital, University of Copenhagen, Denmark; ${ }^{10}$ HistoGeneX, Sint-Bavostraat 78-80, Antwerp 2610, Belgium; ${ }^{11}$ Department of Pathology, Faculty of Medicine, Vrije Universiteit Brussel, Brussels, Belgium; ${ }^{12}$ Pathomation, Berchem, Belgium; ${ }^{13}$ Department of Histopathology, Royal Hallamshire Hospital, Sheffield, UK; ${ }^{14}$ Institute of Pathology, Sheba Medical Center, Tel Hashomer, Israel; ${ }^{15}$ Department of Surgery, Department of Surgical and Perioperative Sciences, Umeå University, Umeå, Sweden; ${ }^{16}$ Department of Oncology \& Metabolism, University of Sheffield, Sheffield, UK; ${ }^{17}$ Valencia Institute of Pathology, Catholic University of Valencia, Valencia, Spain; ${ }^{18}$ Department of Pathology and Oncology, McGill University, Montreal, QC, Canada and ${ }^{19}$ Early Clinical Development, Innovative Medicines and Early Development, AstraZeneca, Cambridge, UK

Background: Liver metastases present with distinct histopathological growth patterns (HGPs), including the desmoplastic, pushing and replacement HGPs and two rarer HGPs. The HGPs are defined owing to the distinct interface between the cancer cells and the adjacent normal liver parenchyma that is present in each pattern and can be scored from standard haematoxylin-and-eosin-stained (H\&E) tissue sections. The current study provides consensus guidelines for scoring these HGPs.

Methods: Guidelines for defining the HGPs were established by a large international team. To assess the validity of these guidelines, 12 independent observers scored a set of 159 liver metastases and interobserver variability was measured. In an independent cohort of 374 patients with colorectal liver metastases (CRCLM), the impact of HGPs on overall survival after hepatectomy was determined.

Results: Good-to-excellent correlations (intraclass correlation coefficient $>0.5$ ) with the gold standard were obtained for the assessment of the replacement HGP and desmoplastic HGP. Overall survival was significantly superior in the desmoplastic HGP subgroup compared with the replacement or pushing HGP subgroup $(P=0.006)$

Conclusions: The current guidelines allow for reproducible determination of liver metastasis HGPs. As HGPs impact overall survival after surgery for CRCLM, they may serve as a novel biomarker for individualised therapies.

*Correspondence: Dr PB Vermeulen; E-mail: Peter.vermeulen2@telenet.be or Dr AR Reynolds; E-mail: andrew.reynolds1@astrazeneca.com Received 29 January 2017; revised 12 June 2017; accepted 30 August 2017; published online 5 October 2017

(C) 2017 Cancer Research UK. All rights reserved 0007-0920/17 
Despite many years of basic and clinical research aimed at curbing tumour growth, metastasis still remains the principle cause of death in the majority of solid tumours. The liver is a frequent site of metastasis for tumours originating from the gastrointestinal tract, pancreas, breast and lung; the liver also hosts metastases of renal cell carcinoma, melanoma and sarcoma (Disibio and French, 2008; Van den Eynden et al, 2013). For example, $\sim 80 \%$ of all metastases from colorectal cancer (CRC) occur in the liver (Schmoll et al, 2012). Approximately $20-25 \%$ of patients with CRC present with liver metastases at the time of diagnosis with a further $20-25 \%$ of patients expected to develop liver metastases at a later date.

We and others have shown that the majority of metastases to the liver present in one of three common distinct histopathological growth patterns (HGPs), known as desmoplastic HGP, pushing HGP or replacement HGP, and two rare HGPs. These HGPs are distinguishable because the interface between the cancer cells of the metastasis and the surrounding normal liver is distinct in each growth pattern. Moreover, the HGPs are recognisable by light microscopy in standard haematoxylin-and-eosin (H\&E)-stained tissue sections (Vermeulen et al, 2001; Stessels et al, 2004; Van den Eynden et al, 2013). The distinct topography of cancer cells in each HGP predicts HGP-specific interactions with parenchymal (hepatocytes and cholangiocytes) and non-parenchymal cells (sinusoidal endothelial cells, stellate cells and immune cells) of the liver. However, despite these clear differences in the biology of these metastases, the molecular drivers of the distinct HGPs remain unknown. It is also currently unclear whether these distinct HGPs require different clinical management strategies.

An overview of previous reports where these HGPs have been studied is provided in Table 1. One of the most important observations made in these studies is that liver metastases with a replacement HGP do not rely on sprouting angiogenesis for a vascular supply but instead co-opt the sinusoidal vasculature of the liver (Vermeulen et al, 2001; Stessels et al, 2004; Frentzas et al, 2016). This is inferred from the specific morphology of replacement-type liver metastases (Masson, 1923; Hamperl, 1956; Elias and Bouldin, 1962; Elias et al, 1964; Vermeulen et al, 2001; Stessels et al, 2004; Frentzas et al, 2016) and is consistent with the small endothelial cell proliferation fraction reported in these metastases (Stessels et al, 2004; Eefsen et al, 2012; Van den Eynden et al, 2012; Vermeulen et al, 2002). This co-option of sinusoidal blood vessels and peri-sinusoidal space (space of Disse) in the replacement HGP is in contrast to the desmoplastic HGP where extensive stromal remodelling and angiogenesis are observed (Vermeulen et al, 2001; Frentzas et al, 2016). Desmoplastic liver metastases have an upregulated uPA-uPAR-PAI-1 proteolytic system and an elevated content of type I and type IV collagens (Illemann et al, 2009; Nystrom et al, 2012; Eefsen et al, 2015).

Interestingly, there is some evidence that the HGP of CRC liver metastases may be predicted by the histology of the primary tumour. Primary CRCs can be classified as having a pushing margin or an infiltrative margin as defined by Jass et al (1987). When liver metastases were classified as being 'encapsulated' (which probably corresponds to the desmoplastic HGP) or nonencapsulated (which probably corresponds to pushing HGP or replacement HGP), 69\% of the primary CRCs with pushing margins, as defined by the Jass criteria (Jass et al, 1987), developed encapsulated liver metastases while only $17 \%$ of primary CRCs with an infiltrative margin developed encapsulated liver metastases (Rajaganeshan et al, 2007). The type of primary cancer can also be predictive of the liver metastases HGP, as almost all breast cancer liver metastases adopt a replacement growth pattern, while liver metastases of CRC can present with any of the different HGPs described (Stessels et al, 2004; Frentzas et al, 2016).

Importantly, the HGPs of liver metastases were shown to have prognostic significance. Both Van den Eynden et al (2012) and
Nielsen et al (2014) studied the impact of the HGPs on overall survival in patients with metastatic CRC. In both studies, the desmoplastic HGP represented superior overall survival. However, in these studies, the results regarding the relative incidence of the different HGPs and the prognostic values of the replacement and pushing HGPs were contradictory. These contradicting results may have been a consequence of differences in the treatment history of the patients in both studies or due to the low number of patient samples that were examined but were likely also due to differences in the methodology used to assess the HGPs. These disparities highlight the need to develop consensus guidelines for scoring the HGPs of liver metastases.

A second important reason to develop such guidelines is the emerging prognostic or predictive value of the HGPs. The clinical and biological diversity of, for instance, CRC liver metastases indeed urges the need for predictive biomarkers to facilitate tailormade treatment strategies (Poston, 2008; Poston et al, 2008). Frentzas et al (2016) demonstrated that CRC liver metastases with a replacement HGP respond poorly to bevacizumab treatment, likely because these tumours utilise vessel co-option instead of angiogenesis. By contrast, desmoplastic liver metastases, which are angiogenic, showed a better response to bevacizumab (Frentzas et al, 2016). These data strongly suggest that HGPs can be used to guide the choice of treatment for individual patients with liver metastases.

Finally, guidelines for scoring the HGPs of liver metastases are important for future mechanistic studies that are aimed at elucidating the molecular drivers of each HGP. These studies will require the establishment of preclinical liver metastasis models that mimic the distinct growth patterns using established cell lines or patient-derived xenografts (PDXs). Studies using such models should lead to identification of novel targets to facilitate precision treatments for patients with liver metastases.

The aims of the current manuscript are therefore to (a) propose consensus guidelines for scoring the HGPs of liver metastases, (b) test the analytical validity of these guidelines, (c) validate the prognostic significance of the HGPs of liver metastasis, (d) speculate on the molecular mechanisms that may underlie the differences in the growth patterns, and (e) highlight future research directions for growth pattern research.

\section{METHODS}

Constructing the guidelines. The team of experts responsible for the proposed guidelines consists of members of the Liver Metastasis Research Network (www.lmrn.org) all of whom have had experience in the assessment of the HGPs of liver metastases. Based on many observations in previous studies on HGPs (Vermeulen et al, 2001, 2002; Eefsen et al, 2012, 2015; Van den Eynden et al, 2012, 2013; Frentzas et al, 2016), and consequently multiple discussions at annual meetings of the LMRN, consensus was reached on a systematic approach to assessing the HGPs. A draft manuscript was produced by a writing committee and was circulated to all the co-authors. Final approval of the guidelines occurred during the annual meeting of the LMRN on 16-17 June 2016 in Umeå, Sweden.

Agreement in HGP score between different samples from the same metastasis. The extent of agreement in HGP score between different samples from the same lesion was addressed in 50 liver metastases of CRC for which $\geqslant 4$ formalin-fixed-paraffinembedded (FFPE) blocks were available for scoring. The samples used for this analysis were obtained from the Department of Surgical Oncology of the Erasmus MC Cancer Institute (Rotterdam, The Netherlands). The total number of blocks included in the analysis was 234 , median number of blocks available per lesion was 
Table 1. Overview of the studies that have addressed the association of the histopathological growth patterns (HGP) of liver metastases with clinical and pathological parameters

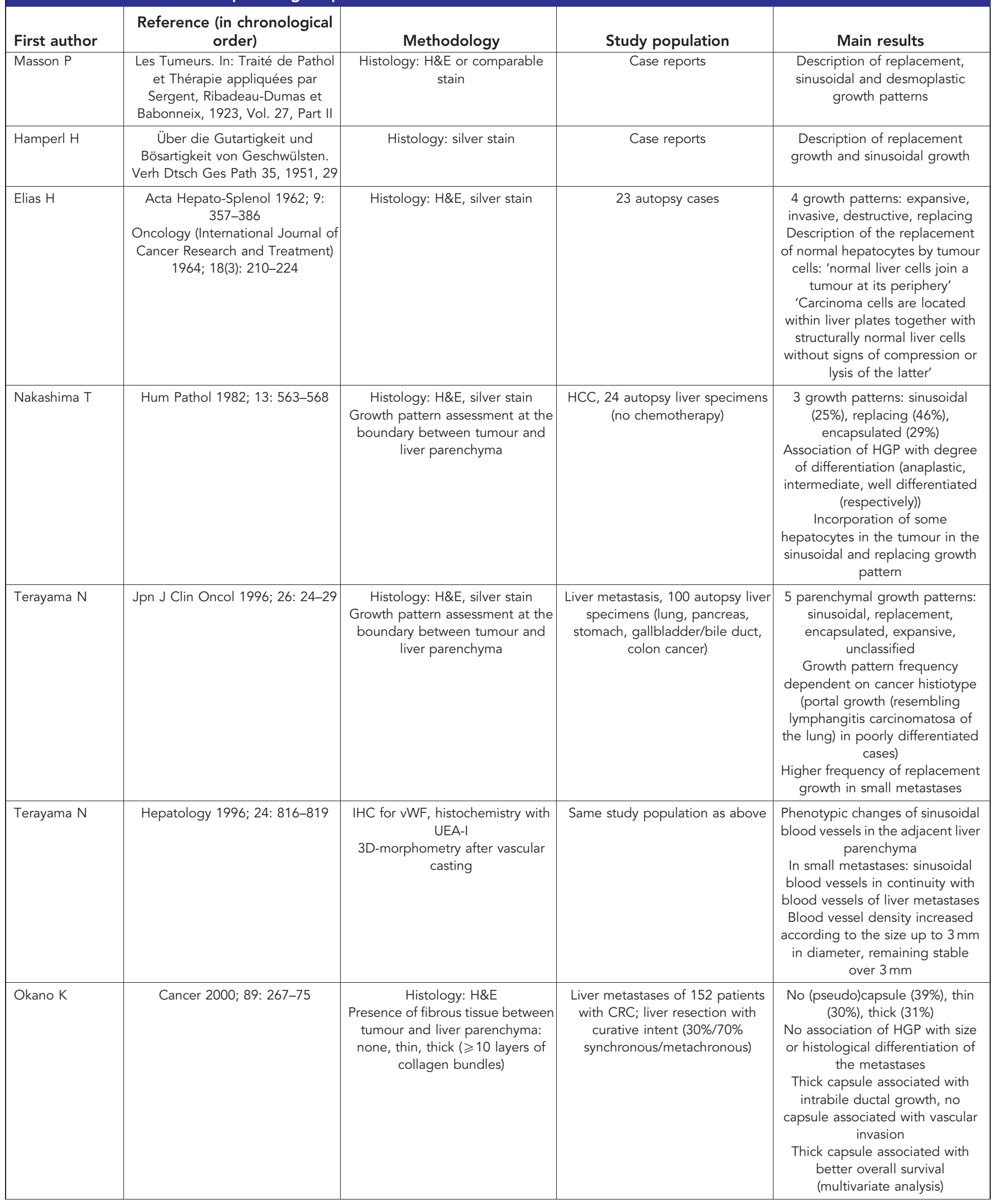




\section{Table 1. (Continued)}

\begin{tabular}{|c|c|c|c|c|}
\hline First author & $\begin{array}{c}\text { Reference (in chronological } \\
\text { order) }\end{array}$ & Methodology & Study population & Main results \\
\hline Lunevicius $\mathrm{R}$ & $\begin{array}{c}\text { J Cancer Res Clin Oncol 2001; } \\
\text { 127:193-199 (comparable results } \\
\text { in: Ohlsson B et al, World J Surg } \\
\text { 1998; 22:268-277 and Morino T } \\
\text { et al, Arch Jpn Chir 1991; } \\
\text { 60: 154-164) }\end{array}$ & $\begin{array}{c}\text { Histology: H\&E } \\
\text { Non-capsule: tumour cells face the } \\
\text { hepatic parenchyma directly (no } \\
\text { fibrous capsule); Capsule: fibrous } \\
\text { band of 0,5 mm thickness or more } \\
\text { Intermediate } \\
\text { IHC for } \alpha \text {-smooth muscle actin, } \\
\text { desmin, vimentin, CD-8, CD-68, } \\
\text { collagen Type I, MMP-1, MMP-2 } \\
\text { and TIMP-1 }\end{array}$ & $\begin{array}{c}\text { Liver metastases of } 69 \text { patients } \\
\text { with CRC }\end{array}$ & $\begin{array}{c}\text { Non-capsule (45\%), intermediate } \\
(35 \%) \text {, capsule }(20 \%)=20 \% \\
\text { 'encapsulated' } \\
\text { Encapsulation more frequently } \\
\text { around differentiated metastatic } \\
\quad \text { cancers } \\
\text { Increased survival rates related to } \\
\text { encapsulation (5 year, not } \\
\text { long-term) }\end{array}$ \\
\hline Vermeulen PB & J Pathol 2001; 195: 336-342 & $\begin{array}{l}\text { Histology: H\&E, silver stain } \\
\text { Liver metastasis HGP } \\
\text { (dominant HGP) } \\
\text { IHC: double-staining for CD31/ } \\
\text { Ki67 and for CD34/ } \alpha \text {-SMA } \\
\text { IHC for caspase cleavage site } \\
\text { of CK18 }\end{array}$ & $\begin{array}{c}\text { Liver metastases of } 26 \text { patients } \\
\text { with CRC (chemonaive/elective } \\
\text { surgery/one metastasis per } \\
\text { patient) }\end{array}$ & $\begin{array}{l}\text { Desmoplastic (42\%), pushing } \\
(46 \%), \text { replacement }(12 \%) \text { (dense, } \\
\text { mild and no inflammatory } \\
\text { infiltrate, respectively) } \\
\text { Highest ECP and highest } \\
\text { ECP/TCP in pushing HGP } \\
\text { Higher fraction of immature } \\
\text { microvessels in the desmoplastic } \\
\text { versus the pushing GP }\end{array}$ \\
\hline Stessels F & $\begin{array}{c}\text { British Journal of Cancer 2004; 90, } \\
\text { 1429-1436 }\end{array}$ & $\begin{array}{c}\text { Histology: H\&E } \\
\text { Liver metastasis HGP (according to } \\
\text { Vermeulen et al, 2001) } \\
\text { IHC for CAIX, CD68, fibrin, LYVE-1 }\end{array}$ & $\begin{array}{c}\text { Liver metastases of } 45 \text { patients } \\
\text { with BC ( } 28 \text { necropsy cases) and } \\
28 \text { patients with CRC (surgical } \\
\text { resection specimens) }\end{array}$ & $\begin{array}{l}\text { HGP is cancer type-dependent. } \\
\text { BC: desmoplastic (2\%), pushing } \\
(2 \%) \text {, replacement }(96 \%) \text {; CRC: } \\
\text { desmoplastic }(50 \%), \text { pushing } \\
(18 \%) \text {, replacement }(32 \%) \\
\text { Less CAIX, less fibrin and less } \\
\text { macrophages in the BC } \\
\text { metastases and in the } \\
\text { replacement-type metastases } \\
\text { of CRC } \\
\text { Cooption of LYVE-1-positive } \\
\text { sinusoidal blood vessels in } \\
\text { replacement HGP }\end{array}$ \\
\hline Illeman M & $\begin{array}{c}\text { Int J Cancer 2009; 124: 1860-1870 } \\
\text { Comment by Van den Eynden G } \\
\text { et al Int J Cancer 2009; } \\
\text { 125: } 1494-1495\end{array}$ & $\begin{array}{c}\text { Histology: silver stain } \\
\text { Liver metastasis HGP (according to } \\
\text { Vermeulen et al, 2001) } \\
\text { Invasive margin of primary CRC } \\
\text { (according to Jass-criteria) } \\
\text { IHC: uPAR, PAI-1, LN5 } \gamma 2 \\
\text { ISH: UPA }\end{array}$ & $\begin{array}{c}14 \text { liver metastases and matched } \\
\text { primary CRC (14 patients ( } 1-5 \\
\text { metastases/patient)) (43\%/57\% } \\
\text { synchronous/metachronous) }\end{array}$ & $\begin{array}{c}\text { No correlation between the } \\
\text { degree of cancer cell budding in } \\
\text { the CRC and the HGP of liver } \\
\text { metastases } \\
\text { Desmoplastic GP }(43 \%) \text {, pushing } \\
(57 \%) \text {, replacement }(0 \%) \\
\text { Upregulation (as in all primary } \\
\text { CRC) of uPA-PAl system in } 5 / 6 \\
\text { desmoplastic }<>0 / 8 \text { pushing } \\
\text { metastases } \\
\text { Differences between activity of } \\
\text { uPA-PAl system between } \\
\text { primary breast carcinoma and } \\
\text { liver metastases of breast cancer }\end{array}$ \\
\hline Nyström H & $\begin{array}{l}\text { Anticancer Research 2012; 32: } \\
\text { 5183-5192 }\end{array}$ & $\begin{array}{c}\text { Histology: H\&E and chemical } \\
\text { reticular staining; dominant } \\
\text { pattern was used, largest } \\
\text { metastasis was used if multiple } \\
\text { metastases } \\
\text { Picro-Sirius Red staining for type I } \\
\text { and type III collagens } \\
\text { IHC for type I and type IV } \\
\text { collagens } \\
\text { HGP according to Vermeulen } \\
\text { et al, } 2001\end{array}$ & $\begin{array}{l}\text { Liver metastases of } 48 \text { patients } \\
\text { with colorectal cancer (fraction } \\
\text { with neo-adjuvant treatment) }\end{array}$ & $\begin{array}{c}\text { Desmoplastic (47\%) and pushing } \\
(53 \%), \text { no replacement HGP (0\%) } \\
\text { Higher levels of type I and type IV } \\
\text { collagen in desmoplastic } \\
\text { metastases } \\
\text { Shorter overall survival in patients } \\
\text { with pushing metastases } \\
\text { No prediction of HGP by } \\
\text { analysing the characteristics of } \\
\text { the primary CRC } \\
\text { No association of size of the liver } \\
\text { metastases and HGP }\end{array}$ \\
\hline
\end{tabular}




\section{Table 1. (Continued)}

\begin{tabular}{|c|c|c|c|c|}
\hline First author & $\begin{array}{c}\text { Reference (in chronological } \\
\text { order) }\end{array}$ & Methodology & Study population & Main results \\
\hline $\begin{array}{l}\text { Van den } \\
\text { Eynden } G\end{array}$ & $\begin{array}{c}\text { Clin Exp Metastasis 2012; } \\
\text { 29: } 541-549\end{array}$ & $\begin{array}{l}\text { Histology: H\&E, silver stain } \\
\text { HGP assessment at the boundary } \\
\text { between tumour and liver } \\
\text { parenchyma: one GP if }>75 \% \text { of } \\
\text { interface, mixed if GPs }>25 \% \text { of } \\
\text { interface } \\
\text { IHC double-staining for CD34/ } \\
\text { Ki67 and staining for CAIX }\end{array}$ & $\begin{array}{l}\text { Liver metastases of } 205 \text { patients } \\
\text { with colorectal cancer; resections } \\
\text { with curative intent }(50 \% / 50 \% \\
\text { synchronous /metachronous) }\end{array}$ & $\begin{array}{l}\text { 27,8\% replacement; } 15,6 \% \\
\text { pushing; } 34,6 \% \text { desmoplastic; } \\
17,6 \% \text { mixed ( } n=9 \text { :insufficient } \\
\text { sampling of interface) } \\
\text { ECP (\%) highest in pushing HGP, } \\
\text { TCP (\%) lowest in replacement } \\
\text { HGP } \\
\text { Higher ECP and TCP if CAIX } \\
\text { expression at interface } \\
\text { Metastases with pushing HGP } \\
\text { larger than desmoplastic/ } \\
\text { replacement HGP } \\
\text { At } 2 \text { year FU: lower survival } \\
\text { fraction in the group with } \\
\text { pushing component }\end{array}$ \\
\hline Pinheiro RS & Am J Surg 2014; 207: 493-498 & $\begin{array}{l}\text { Histology: H\&E (according to } \\
\text { criteria reported by Jass et al for } \\
\text { primary CRC: 'pushing' and } \\
\text { 'infiltrative' }\end{array}$ & $\begin{array}{l}91 \text { patients with CRC liver } \\
\text { metastases (mean number of } \\
\text { lesions of 2.9) }\end{array}$ & $\begin{array}{l}\text { Infiltrative margins (resembling } \\
\text { replacement growth) as } \\
\text { independent risk factor for } \\
\text { recurrence and inferior 5-year } \\
\text { DFS rate }\end{array}$ \\
\hline Eefsen RL & $\begin{array}{c}\text { Clin Exp Metastasis 2015; 32: } \\
\text { 369-381 }\end{array}$ & $\begin{array}{l}\text { Histology: H\&E, silver stain } \\
\text { (according to Vermeulen et al, } \\
2001 ; 75 \% \text { cutoff for dominant } \\
\text { growth pattern) }\end{array}$ & $\begin{array}{l}224 \text { CRC liver metastases } \\
\text { obtained from } 224 \text { patients } \\
\text { (largest metastasis only) }\end{array}$ & $\begin{array}{l}\text { Recurrence-free survival longer if } \\
\text { desmoplastic HGP then if } \\
\text { replacement HGP (both for } \\
\text { chemonaive patients and } \\
\text { patients who received neo- } \\
\text { adjuvant treatment) }\end{array}$ \\
\hline Eefsen RL & $\begin{array}{l}\text { Cancer Microenviron 2015; 8(2): } \\
\text { 93-100 }\end{array}$ & $\begin{array}{l}\text { Histology: H\&E, silver stain } \\
\text { (according to Vermeulen et al, } \\
\text { 2001; } 75 \% \text { cutoff for dominant } \\
\text { growth pattern) } \\
\text { IHC for uPAR, CD3, CD68 }\end{array}$ & $\begin{array}{l}237 \text { CRC liver metastases from } 237 \\
\text { patients (selection of one } \\
\text { metastasis per patient based on } \\
\text { regression grade) }\end{array}$ & $\begin{array}{l}\text { In untreated patients only: higher } \\
\text { expression of uPAR in the } \\
\text { desmoplastic HGP and higher } \\
\text { number of macrophages (CD68) } \\
\text { in the replacement HGP }\end{array}$ \\
\hline Kuczynski EA & J Natl Cancer Inst 2016; 108 (8) & $\begin{array}{c}\text { Histology } \\
\begin{array}{c}\text { Contrast-enhanced ultrasound } \\
\text { (vessel perfusion) }\end{array} \\
\text { miRNA sequencing and qRT-PCR }\end{array}$ & $\begin{array}{c}\text { Orthotopic human } \mathrm{HCC} \text { model to } \\
\text { study sorafenib resistance }\end{array}$ & $\begin{array}{l}\text { Resistance based on a change of } \\
\text { growth pattern with vessel } \\
\text { co-option during treatment }\end{array}$ \\
\hline
\end{tabular}




\section{Table 1. (Continued)}

\begin{tabular}{|c|c|c|c|c|}
\hline First author & $\begin{array}{c}\text { Reference (in chronological } \\
\text { order) }\end{array}$ & Methodology & Study population & Main results \\
\hline Siriwardana PN & Medicine 2016; 95(8): e2924 & $\begin{array}{l}\text { Histology: H\&E ('infiltrative' and } \\
\text { 'encapsulated' HGP; } 75 \% \text { cutoff } \\
\text { for dominant growth pattern) }\end{array}$ & $\begin{array}{l}30 \text { patients with CRC liver } \\
\text { metastases. No presurgical } \\
\text { systemic treatment. One randomly } \\
\text { selected metastasis per patient }\end{array}$ & $\begin{array}{l}\text { Longer overall survival if } \\
\text { encapsulated liver metastasis }\end{array}$ \\
\hline Frentzas S & $\begin{array}{l}\text { Nature Medicine 2016; 22: } \\
\qquad 1294-1302\end{array}$ & $\begin{array}{l}\text { Histology: H\&E (according to the } \\
\text { current guidelines) }\end{array}$ & $\begin{array}{c}152 \text { CRC liver metastases from } 79 \\
\text { patients }\end{array}$ & $\begin{array}{l}\text { The HGPs predict response to } \\
\text { bevacizumab chemotherapy } \\
\text { treatment and survival. Patients } \\
\text { with liver metastases with a } \\
\text { replacement growth pattern have } \\
\text { a less favourable outcome }\end{array}$ \\
\hline \multicolumn{5}{|c|}{ 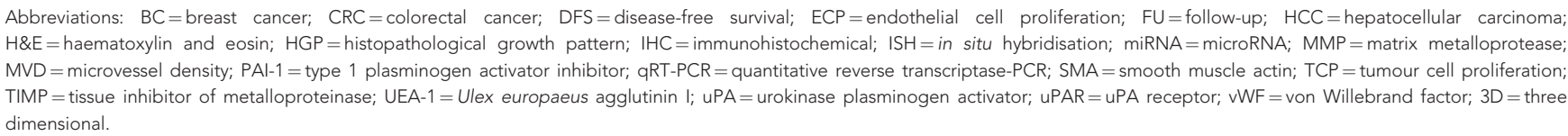 } \\
\hline
\end{tabular}

4 (range $=4-16$ blocks per lesion). H\&E-stained sections from all 234 blocks were scored for HGP by EPvdS, RRJCvdB, BG and PBV according to the proposed guidelines (a consensus score was agreed upon during multiple sessions at a multihead microscope). Each block was then assigned to an HGP category: those scored as $>50 \%$ desmoplastic were categorised as predominant desmoplastic HGP ( $n=121$ blocks), those scored as $>50 \%$ pushing were categorised as predominant pushing HGP ( $n=7$ blocks), and those scored as $>50 \%$ replacement were categorised as predominant replacement HGP ( $n=98$ blocks). In the case that no predominant HGP was found, the block was categorised as having a mixed HGP ( $n=8$ blocks). In order to determine the extent of agreement in HGP score between different blocks derived from the same lesion, for each of the 50 lesions we calculated the percentage of blocks that fell into the same category.

Analytical validation study. For the analytical validation of the guidelines, representative H\&E-stained sections from $159 \mathrm{FFPE}$ sections of CRC $(n=129)$ and breast cancer (BC) $(n=30)$ liver metastases (obtained from patients undergoing routine resection) were retrieved from the archives of the pathology laboratory of the St Augustinus Hospital (GZA Hospitals), Wilrijk-Antwerp, Belgium. This set was then divided into a training set of 60 metastases and a validation set of 99 metastases by PBV and GGvdE. The sections were scanned on a 3DHISTECH (3DHISTECH Ltd., Budapest, Hungary) scanning device. Explanatory notes were provided for each of the images in the training set. These notes included the 'gold standard' HGP score, that is, the consensus HGP score as agreed by two pathologists (PBV and GGvdE) with $>10$ years of experience in scoring the HGPs. The images and the explanatory notes were then uploaded to the 'Pathomation whole slide image viewer' (Pathomation BVBA, Antwerp, Belgium) on the website of the Liver Metastasis Research Network (www.lmrn.org). The decision tree and the guidelines (Figure 1 and Tables 2 and 3, respectively) were also published on this website.

Twelve participants volunteered to take part in the validation study. Of these 12 participants, only 4 had prior experience of scoring liver metastasis growth patterns, while the remaining 8 participants had no prior experience of scoring liver metastasis growth patterns. Of these 12 participants, only 3 were professionally trained pathologists, while the remaining 9 participants were scientists with either a biological sciences or medical background. Participants were given access to the data on the website of the Liver Metastasis Research Network. The participants were first asked to study the decision tree and the guidelines so that they could understand how HGPs are to be scored. They were then asked to examine the training set and the explanatory notes. Once these tasks were completed, they were then given access to the validation set of 99 liver metastases and asked to record their HGP scores for each of the cases. The participants assessed the HGPs of each metastasis (percentage of interface occupied by a growth pattern for all growth patterns present in $>5 \%$ of the length of the interface) and submitted their results electronically within the Pathomation image viewer. The submitted results were then compared with the preestablished 'gold standard'.

Clinical validation study. The clinical validity was assessed by a survival analysis. For this we used representative H\&E-stained tissue sections of FFPE CRC liver metastases from 374 patients who underwent surgical resection at the Department of Surgical Oncology of the Erasmus MC Cancer Institute (Rotterdam, The Netherlands) between 2000 and 2015. The HGPs were determined by EPvdS, RRJCvdB, BG and PBV according to the proposed guidelines (for patient details, see Table 4). A consensus score was agreed upon during multiple sessions at a multihead microscope. Patients for whom $>50 \%$ of the tumour-liver interface was identified as exhibiting one of the three HGP were allocated to a group labelled as predominantly of this HGP (i.e., $>50 \%$ desmoplastic were categorised as predominant desmoplastic HGP; $>50 \%$ pushing were categorised as predominant pushing HGP; $>50 \%$ replacement were categorised as predominant replacement HGP). In cases of multiple sections per metastasis or multiple liver metastases per patient, the mean percentage was used. Overall survival was considered the time interval between the date of liver metastasis resection and the date of death or last follow-up.

Overall survival analysis using different HGP cutoffs. Survival analyses were also performed using different cut points to define the predominant HGP. Owing to the low numbers of patients presenting with a predominant pushing HGP (only $3 \%$ of patients when using a cutoff of $>50 \%$ ), this analysis was limited to a comparison of replacement HGP patients with desmoplastic HGP patients. Cut points of $>50 \%,>70 \%,>80 \%,>90 \%$ or $100 \%$ were used to define whether a tumour had a predominant replacement HGP or a predominant desmoplastic HGP.

Statistical analysis. Descriptive values are expressed as median (interquartile range). Variables were compared by chi-square analysis, Fisher's exact test or with independent Student's $t$-test or Mann-Whitney $U$-test. The Kaplan-Meier method was used to generate survival estimates, which were compared by Log-rank test. Cox regression models were used to correct for potential confounders. Only parameters with a $P$-value $<0.10$ in the univariate model were entered in the multivariate Cox regression 


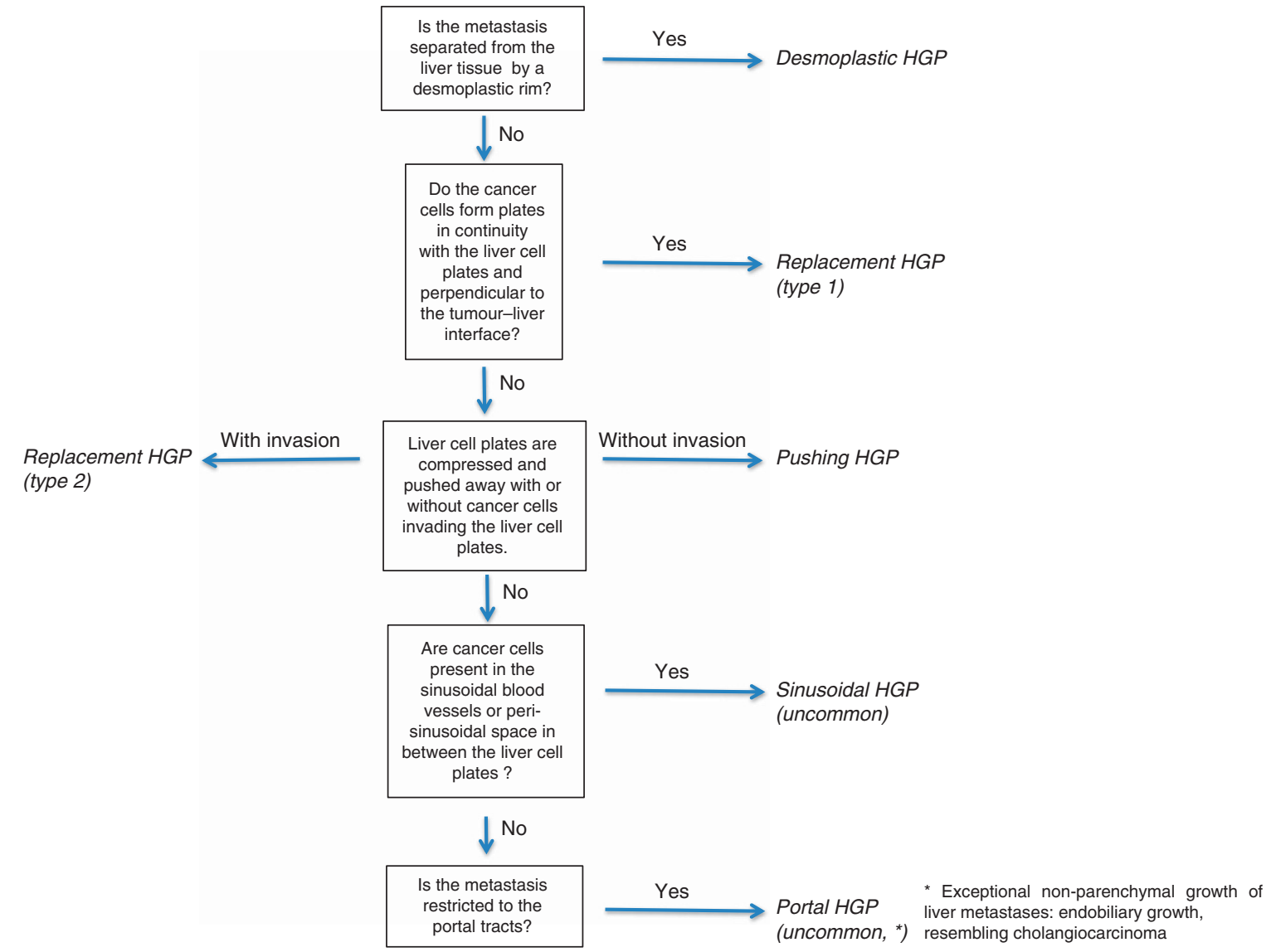

Figure 1. Decision tree to assess the growth patterns of liver metastases based on the key histopathological characteristics.

\section{Table 2. Key histopathological characteristics of the growth patterns of liver metastases}

\begin{tabular}{|c|c|c|c|c|c|}
\hline Histology of interface & Desmoplastic & Pushing & $\begin{array}{c}\text { Replacement (two } \\
\text { types) }\end{array}$ & Sinusoidal & Portal \\
\hline \multicolumn{6}{|l|}{ Obligatory criteria } \\
\hline Architecture & $\begin{array}{l}\text { Desmoplastic rim } \\
\text { between liver and } \\
\text { metastatic tissue }\end{array}$ & $\begin{array}{l}\text { Liver pushed aside by } \\
\text { metastatic tissue }\end{array}$ & $\begin{array}{l}\text { Hepatocytes are } \\
\text { replaced by cancer } \\
\text { cells }\end{array}$ & $\begin{array}{c}\text { Cancer cells grow in the } \\
\text { sinusoidal vessels or in } \\
\text { the peri-sinusoidal space } \\
\text { (Disse) }\end{array}$ & $\begin{array}{l}\text { Proliferation of } \\
\text { cancer cells within } \\
\text { portal tracts and } \\
\text { septa }\end{array}$ \\
\hline $\begin{array}{l}\text { Mimicking of liver architecture } \\
\text { Invasion around sinusoidal } \\
\text { capillaries }\end{array}$ & $\begin{array}{l}- \\
-\end{array}$ & $\begin{array}{l}- \\
-\end{array}$ & $\begin{array}{c}++ \\
+(+ \text { Disse space })\end{array}$ & $\begin{array}{c}+ \\
++\end{array}$ & $\begin{array}{l}- \\
-\end{array}$ \\
\hline $\begin{array}{l}\text { Invasion of cancer cells in the } \\
\text { liver cell plates with direct } \\
\text { contact between hepatocytes } \\
\text { and cancer cells }\end{array}$ & - & - & ++ & - & - \\
\hline Desmoplastic reaction & ++ & - & - & - & $-1+$ \\
\hline $\begin{array}{l}\text { Compression of liver cell plates } \\
\text { Contour }\end{array}$ & $\stackrel{+}{+}$ & $\begin{array}{l}++ \\
\text { Sharp }\end{array}$ & $\begin{array}{c}-/+ \\
\text { Irregular }\end{array}$ & $\stackrel{-}{\text { Irregular }}$ & $\stackrel{-}{-}$ \\
\hline \multicolumn{6}{|l|}{ Additional criteria } \\
\hline $\begin{array}{l}\text { Inflammatory infiltrate } \\
\text { Glandular differentiation } \\
\text { (adenocarcinoma) } \\
\text { Proliferation of bile ducts }\end{array}$ & $\begin{array}{c}++ \\
\text { Well differentiated } \\
+/-\end{array}$ & $\begin{array}{c}+/-^{a} \\
\text { Well differentiated } \\
-\end{array}$ & $\begin{array}{c}-{ }^{\mathrm{a}} \\
\text { Moderately to poorly } \\
\text { differentiated } \\
-\end{array}$ & $\begin{array}{c}-^{\mathrm{a}} \\
\text { Poorly differentiated } \\
-\end{array}$ & $\begin{array}{c}+ \\
\text { Well to moderately } \\
\text { differentiated } \\
-/+\end{array}$ \\
\hline \multicolumn{6}{|l|}{ Caution } \\
\hline $\begin{array}{l}\text { Portal tracts } \\
\text { Liver capsule }\end{array}$ & \multicolumn{5}{|c|}{$\begin{array}{l}\text { Do not score as desmoplastic area } \\
\text { Do not score HGP when near liver capsule }\end{array}$} \\
\hline
\end{tabular}


Table 3. Standard method for histopathological growth pattern assessment of liver metastases

- The growth pattern is a histological parameter assessed by light microscopic imaging of haematoxylin-and-eosin sections of FFPE tissue of liver metastases.

- The histological growth patterns of liver metastases can be evaluated by a pathologist or by any other investigator trained by a pathologist.

- The growth pattern is a characteristic of the tumour-liver interface. The centre of the metastasis does not contribute to the classification of a growth pattern

- A histochemical silver impregnation staining of the sections (e.g., GordonSweet's reticulin staining) has added value to discern fibrosis/preservation of the supportive tissue architecture of the spaces of Disse and sinusoids.

- The three common growth patterns are: desmoplastic, pushing and replacement (type 1 and type 2).

- Two rare growth patterns are: sinusoidal and portal.

- When more than one growth pattern is present in a metastasis: estimate the relative fraction of each growth pattern with a length of $\geqslant 5 \%$ of the total length of the interface (e.g., $80 \%$ desmoplastic/20\% pushing; $95 \%$ replacement $/ 5 \%$ pushing).

- In case of multiple metastases/patient: assess the growth pattern(s) in every individual liver metastasis and note the anatomical position.

- Caveats.

Portal tracts at the tumour-liver interface should not be evaluated as areas with a desmoplastic growth pattern

Reactive ductular proliferation in the desmoplastic rim can simulate a replacement growth pattern.

Metastases with a replacement growth pattern usually have no or a very mild inflammatory infiltrate. Exceptionally, these metastases can have a dense infiltrate.

Metastases adjacent to the liver capsule should be assessed with caution to avoid overestimation of desmoplastic growth.

Tissue cores from needle biopsy procedures cannot be used to assess the growth pattern of liver metastases.

If $<20 \%$ of the expected interface is present in the tissue section, a disclaimer stating 'insufficient tumour-liver interface' should be added. Delayed fixation (e.g., autopsy cases) or radiofrequency ablation can impair the quality of the tissue so that reliable assessment of growth patterns is not possible.

If no viable tumour tissue is present in the metastasis, this should be mentioned (treatment effect: fibrosis, infarct-type necrosis, acellular mucin lakes).

model. The SPSS statistical package (version 21.0, SPSS, Chicago, IL, USA) was used. A $P$-value $\leqslant 0.05$ was considered statistically significant.

\section{RESULTS}

Guidelines for scoring the HGPs of liver metastases. In these guidelines, three common (desmoplastic HGP, pushing HGP and replacement HGP) and two rare (sinusoidal HGP and portal HGP) growth patterns are described that can all be identified in H\&Estained specimens of FFPE liver metastases. The key histopathological characteristics of the HGPs are summarised in Table 2. The consensus guidelines for scoring the HGPs are summarised in Table 3. In order to assist the observer in scoring the different HGPs, we have constructed a decision tree that can be easily followed to determine the growth pattern (Figure 1).

In the desmoplastic HGP, the cancer cells of the metastasis are separated from the liver tissue by a rim of desmoplastic tissue (Figures 2A-D). The metastasis does not mimic the liver architecture and there is no direct contact between cancer cells and hepatocytes. New blood vessels in the desmoplastic rim are formed by sprouting angiogenesis. There is often a dense lymphocytic infiltrate at the interface of the desmoplastic and liver tissue that can sometimes obscure the interface (Figure 2E). A proliferation of bile ducts, often called 'ductular reaction', can sometimes be seen surrounding the desmoplastic metastasis (Figure 2E). It is important to note that portal tracts that lie
Table 4. Clinicopathological characteristics in the clinical validation cohort

\begin{tabular}{|c|c|c|}
\hline & \multicolumn{2}{|c|}{ All patients $(N=374)$} \\
\hline Variables & Value & $\%$ or IQR \\
\hline Male & 241 & $64 \%$ \\
\hline Age, median & 63 & $57-70$ \\
\hline \multicolumn{3}{|l|}{ Primary tumour } \\
\hline Rectal cancer & 170 & $46 \%$ \\
\hline $\mathrm{T} 3 / \mathrm{T} 4$ & 273 & $79 \%$ \\
\hline Positive lymph node & 211 & $61 \%$ \\
\hline Adjuvant CTx & 70 & $19 \%$ \\
\hline \multicolumn{3}{|l|}{ Liver metastases } \\
\hline CEA $>200 \mathrm{ng} \mathrm{ml}^{-1}$ & 23 & $8 \%$ \\
\hline Synchronous (<1 year) & 243 & $66 \%$ \\
\hline Diameter Largest $>5 \mathrm{~cm}$ & 67 & $18 \%$ \\
\hline Number of metastases $>1$ & 234 & $63 \%$ \\
\hline Bilobar & 153 & $41 \%$ \\
\hline Neo-adjuvant Ctx & 206 & $56 \%$ \\
\hline Neo-adjuvant Ctx + bevacizumab & 59 & $16 \%$ \\
\hline $\mathrm{R} 1$ resection & 99 & $27 \%$ \\
\hline Extrahepatic disease & 45 & $12 \%$ \\
\hline CRS 3-5 & 139 & $38 \%$ \\
\hline \multicolumn{3}{|c|}{$\begin{array}{l}\text { Abbreviations: } \quad C E A=\text { carcinoembryonic antigen; } \\
\text { chemotherapy; } I Q R=\text { interquartile range. }\end{array}$} \\
\hline
\end{tabular}

directly adjacent to a metastasis should not be confused with the desmoplastic tissue (Figure 2F). Also, areas directly underneath the liver capsule should not be confused with desmoplastic tissue.

In the pushing HGP, the liver cell plates that surround the metastasis are pushed away and are compressed (Figures $3 \mathrm{~A}-\mathrm{C}$ ). There is no desmoplastic rim surrounding the metastasis but also no direct contact between cancer cells and hepatocytes within the liver cell plates. As in the desmoplastic HGP, the metastasis does not mimic the liver architecture.

In the replacement HGP, cancer cells form cell plates that are in continuity with the liver cell plates (Figures 4A-E). This permits the cancer cells to replace the hepatocytes within the liver cell plates and allows these metastases to co-opt the sinusoidal blood vessels at the tumour-liver interface, without inducing sprouting angiogenesis. There are two subtypes of the replacement HGP. In the first type (type 1) the liver cell plates used by the cancer cells are perpendicular to the tumour-liver interface (Figures $4 \mathrm{~B}$ and $\mathrm{C}$ ), and in the second type (type 2), the liver cell plates are pushed away while the cancer cells replace the hepatocytes (Figures $4 \mathrm{D}$ and E). The latter type of replacement HGP should not be confused with the pushing HGP (Figures $3 \mathrm{~A}-\mathrm{C}$ ).

There are two rare HGPs of liver metastases, namely, the sinusoidal HGP and the portal HGP. In the sinusoidal HGP, the cancer cells are present as emboli within the lumens of the sinusoidal blood vessels and/or grow in the peri-sinusoidal space (Figure 5). As the cancer cells do not exit the blood vessels or enter the liver cell plates, there is no cell-cell contact between the cancer cells and the hepatocytes in this sinusoidal HGP. As in the replacement HGP, the sinusoidal blood vessels are co-opted as a means of vascularisation. In our experience, the sinusoidal HGP occurs in patients with rapidly progressing liver metastases and is therefore often encountered in autopsy specimens (Allison et al, 2004; Simone et al, 2012). In the portal HGP, the growth of cancer is restricted to the connective tissue areas of the portal tracts, liver septa and liver capsule. The portal HGP has been detected in animal models of liver metastases by us and only very infrequently in human BC or CRC liver metastases.

The current guidelines also address the fact that a liver metastasis may have more than one growth pattern. In order to collect all the available information for subsequent data analysis, the guidelines propose to estimate the relative fraction of each 

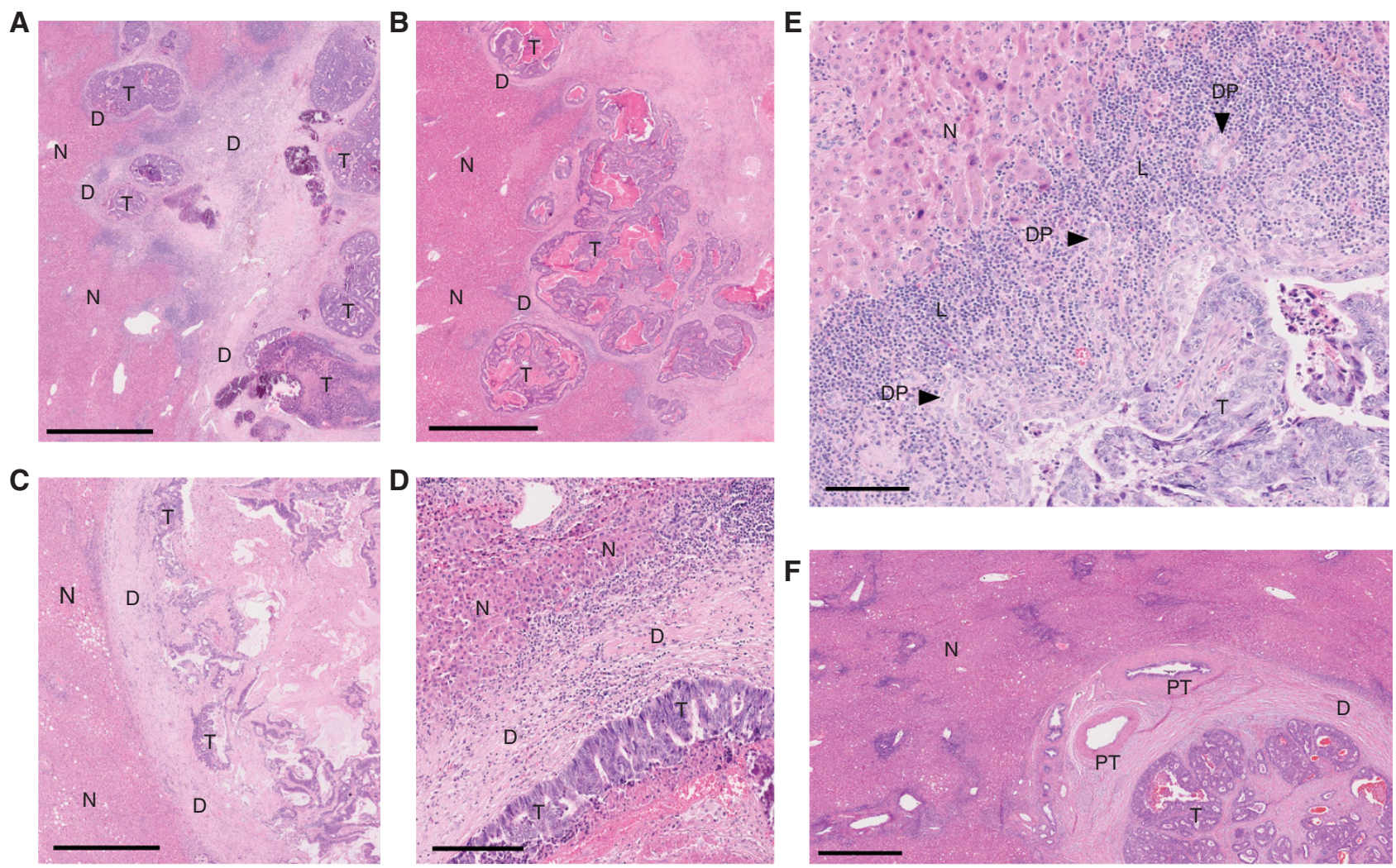

Figure 2. H\&E images of the desmoplastic histopathological growth pattern. (A-C) Low magnification images of the desmoplastic histopathological growth pattern. (D) Higher magnification image of the desmoplastic histopathological growth pattern. (E) Desmoplastic histopathological growth pattern with ductular proliferation (also known as ductular reaction) and dense lymphocyte infiltrate. (F) Portal tracts at the tumour-liver interface. D, desmoplastic rim; DP, ductular proliferation; L, lymphocyte infiltrate; N, normal liver parenchyma; PT, portal tract; T, vital tumour tissue. Scale bar $=1000 \mu \mathrm{M}(\mathbf{A}-\mathbf{C}$ and $\mathbf{F}), 100 \mu \mathrm{M}$ (D and $\mathbf{E})$.

HGP that constitutes $\geqslant 5 \%$ of the total length of the interface. In the typical pathology archive, there may be either one tissue block available per liver lesion or multiple tissue blocks available per liver lesion. In the case where multiple blocks are available for a given lesion, we recommend that the HGP from each block is determined. The mean average HGP score should then be calculated to produce a single score for percentage of desmoplastic, percentage of pushing and percentage of replacement HGP for each lesion. In case of multiple liver metastases from a single patient, it is recommended that the HGPs of every individual single lesion be scored separately and the information saved together with the anatomical position of the respective lesion.

Important caveats for scoring the HGPs of liver metastases. In order to score the HGPs correctly, there are issues of concern that are related to the amount of available tumour-liver interface (where the HGPs are assessed), the quality of the tissue and the process of data collection. These points of concern are summarised in Table 3. First, tissue cores from needle biopsy procedures should not be used to assess the HGPs of liver metastases. The obvious reason is that the amount of interface present in a tissue core is minimal and insufficient to cover the possible heterogeneity of the HGPs within a single metastasis. Second, if $<20 \%$ of the expected interface is present in the tissue section, a disclaimer stating 'insufficient tumour-liver interface' should be added. There are various circumstances that may cause $<20 \%$ of the expected interface to be present in the tissue section. These include, but are not limited to, the following: (a) the presence of excessive damage to the tissue section or (b) when a considerable proportion of the tumour present in the section forms a border with the liver capsule rather than forming a border with the liver parenchyma. Third, if no viable tumour tissue is present in the metastasis, scoring the
HGP is not possible. Often this is due to treatment before surgery that causes replacement of the cancerous tissue by areas of fibrosis, infarct-type necrosis or cell-free lakes of mucinous substance. Fourth, an adequate quality of the liver metastasis tissue is essential. Indeed, delayed fixation (e.g., autopsy cases) or radiofrequency ablation can impair the quality of the tissue so that reliable assessment of HGPs is not possible.

Agreement in HGP score between different samples from the same metastasis. When considering the diagnostic utility of the HGPs, one point of concern is whether a single tissue section adequately captures the growth pattern of the entire lesion. In order to address this issue, we examined whether scoring the HGP from a single tissue sample is as accurate as scoring the HGP from multiple tissue samples. To do this, we examined an unselected set of 50 liver metastases for which multiple $(\geqslant 4)$ tissue blocks were available. The median number of blocks available per lesion in this set was four (range $=4-16$ blocks per lesion). A single tissue section from each block was scored for the HGP and then assigned to an HGP category: predominant desmoplastic HGP, predominant pushing HGP, predominant replacement HGP, or mixed HGP (according to strictly defined criteria, as detailed in the Methods section). We then assessed the degree to which blocks from the same lesion fell into the same category. We found that, for $82 \%$ of the lesions examined (41 out of 50 lesions), the HGP category was in complete agreement (100\% agreement) across all blocks tested. Among the 9 other lesions examined, we found agreement between: 4 out of 5 blocks ( $80 \%$ agreement) for two lesions, 3 out of 4 blocks (75\% agreement) for 4 lesions, 3 out of 5 blocks for 2 lesions ( $60 \%$ agreement), and 2 out of 4 blocks for 1 lesion (50\% agreement). There were no cases with an agreement $<50 \%$. 


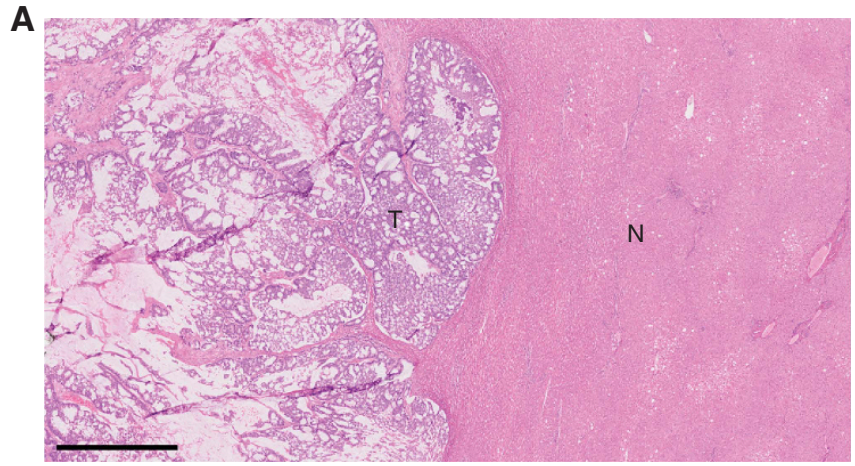

B
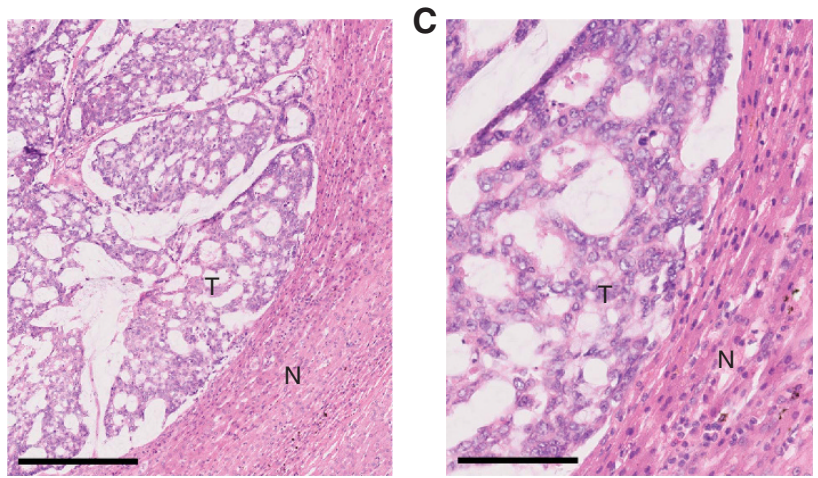

Figure 3. H\&E images of the pushing histopathological growth pattern. (A) Low magnification image of the pushing histopathological growth pattern. (B and $\mathbf{C}$ ) Higher magnification images of the pushing histopathological growth pattern. $N$, normal liver parenchyma; $T$, vital tumour tissue. Scale bar $=500 \mu \mathrm{m}$ (A), $100 \mu \mathrm{m}$ (B), $50 \mu \mathrm{m}$ (C).

Analytical validation of the guidelines to assess the HGPs of liver metastasis. In order to assess the analytical validity of the current guidelines, a validation study was performed. In the first stage, 12 participants (a mixed group composed of 3 pathologists, 4 clinicians and 5 basic scientists) underwent a training exercise, in which they were provided with a copy of the guidelines contained herein and were then asked to score a training set of whole slide digital images of 60 liver metastases. Subsequently, they were provided with a validation set comprising 99 additional whole slide digital images. The scores of this validation set were then used to compare the participants' results with the gold standard.

The results of the validation study were tabulated with rows representing the different participants $(n=12)$ and columns indicating the percentage of interface occupied by a HGP in the set of 99 metastases. Using an intraclass correlation coefficient (ICC), the participants' scores were compared with the gold standard, (i.e., the consensus result of the pathologists GGvdE and PBV). This resulted in ICC coefficients for desmoplastic, pushing, replacement (type 1), replacement (type 2) and replacement (independent of type) HGP for each individual participant. ICC values $>0.5$ represent a good reproducibility and values $>0.7$ an excellent reproducibility. After colour coding and unsupervised hierarchical clustering of the ICC coefficients of each HGP for all participants, the heat map (Figure 6) shows that, for the majority of the participants, good-to-excellent correlations with the gold standard were obtained for replacement (independent of subtype), replacement (type 1) and desmoplastic HGP. This indicates that the key characteristics of the desmoplastic HGP and the replacement HGP were recognisable by most participants. The results also show that the participants found the pushing HGP and the type 2 replacement HGP more difficult to distinguish.

Clinical validation of the guidelines to assess the HGPs of liver metastases: survival analysis. In order to test the prognostic value

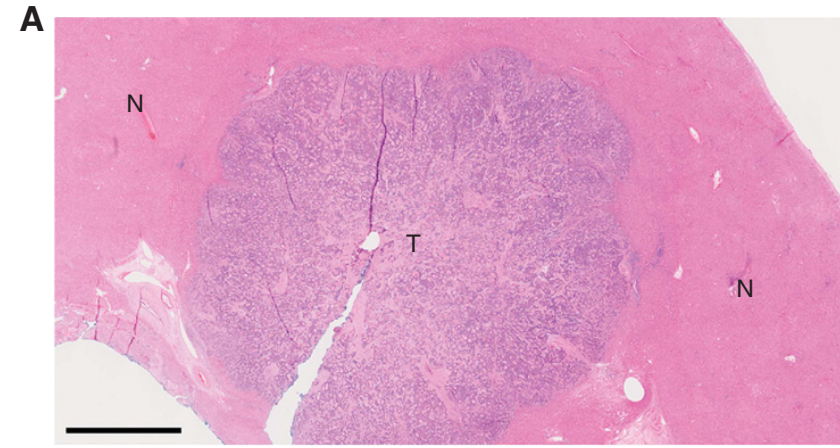

B
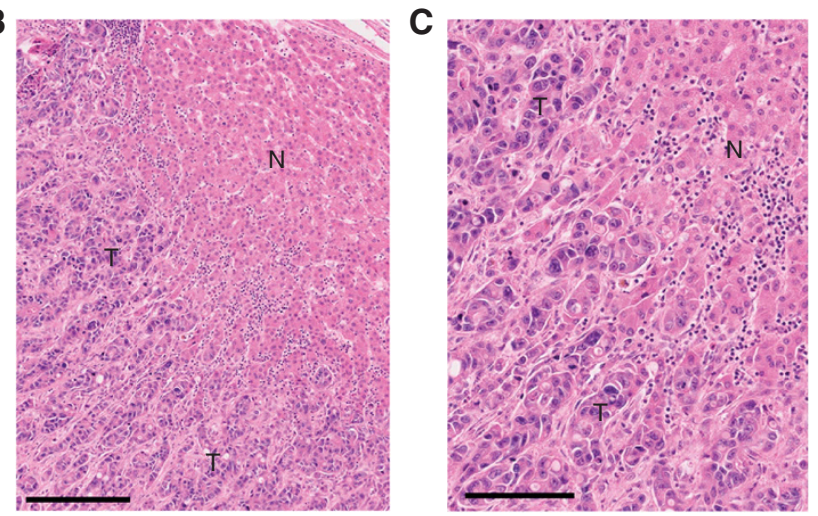

D
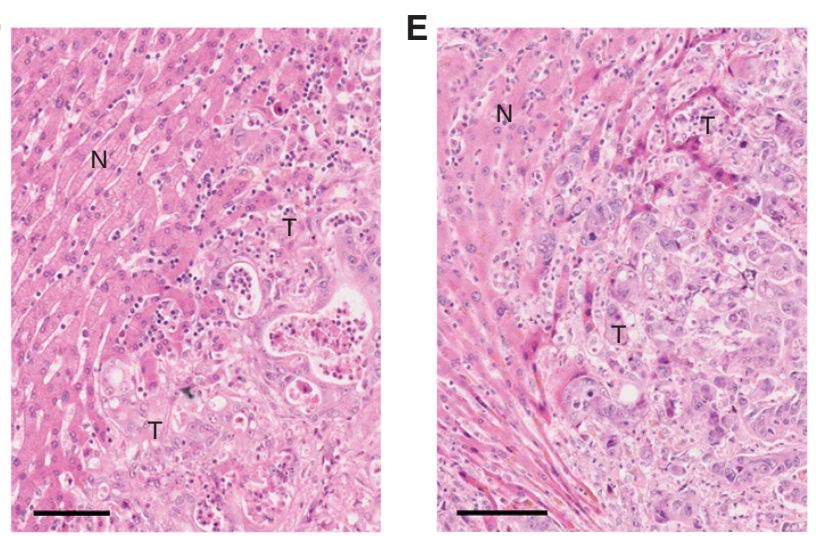

Figure 4. H\&E images of the replacement histopathological growth pattern. (A) Low magnification image of the replacement histopathological growth pattern. (B and $\mathbf{C}$ ) Higher magnification images of the type 1 replacement histopathological growth pattern. ( $D$ and $\mathbf{E}$ ) Higher magnification images of the type 2 replacement histopathological growth pattern. $N$, normal liver parenchyma; $T$, vital tumour tissue. Scale bar $=2000 \mu \mathrm{M}$ (A), $100 \mu \mathrm{M}$ (B, D and E), $50 \mu \mathrm{M}$ (C).

of the growth patterns as scored according to our current guidelines, the HGPs were scored in CRC liver metastases resection specimens from a series of 374 patients (Table 4). Correlation of the HGPs with overall survival was then analysed. For the analysis of overall survival, the 374 patients were stratified into one of the three subgroups. Patients for whom $>50 \%$ of the tumour-liver interface was identified as desmoplastic HGP were classified as predominant desmoplastic HGP, while patients for whom $>50 \%$ of the tumourliver interface was identified as pushing HGP or replacement HGP were classified as predominant pushing HGP or predominant replacement HGP, respectively. According to these criteria, the desmoplastic HGP was predominant in 183 (49\%) patients, the replacement HGP in 177 (47\%) patients and the pushing HGP in 10 (3\%) patients. No dominant HGP could be found in the liver metastases of 4 patients (1\%) and so these patients were excluded from the survival analyses. 
Figure 7 shows the overall survival curves for each subgroup. The median time of follow-up was 34 months (95\% CI: 17-61 months). The median overall survival for the desmoplastic subgroup was 64 months (95\% CI: 51-77 months). For the replacement subgroup median overall survival was 36 months (95\% CI: 30-42 months). Median overall survival was not reached for the pushing subgroup. Overall survival was significantly superior in the desmoplastic subgroup as compared with the replacement or pushing subgroup $(P=0.006$, Figure 7$)$.

According to Table 5, three parameters were significantly different between the distinct HGP subgroups: lymph node status of the primary CRC, absence or presence of metastasis within 1 year after resection of the primary CRC, and systemic treatment prior resection of liver metastasis. The effects on overall survival of these parameters were tested in a univariate Cox regression model. This was also carried out for the clinical risk score (CRS) according to Fong because of its established prognostic value (Fong et al, 1999) (Table 6). In a multivariate analysis, both a poor CRS (3-5) and the presence of a predominant replacement HGP resulted in a significantly shorter overall survival with respective HR of 1.97 (95\% CI: $1.47-2.65)$ and 1.73 (95\% CI: 1.28-2.33).

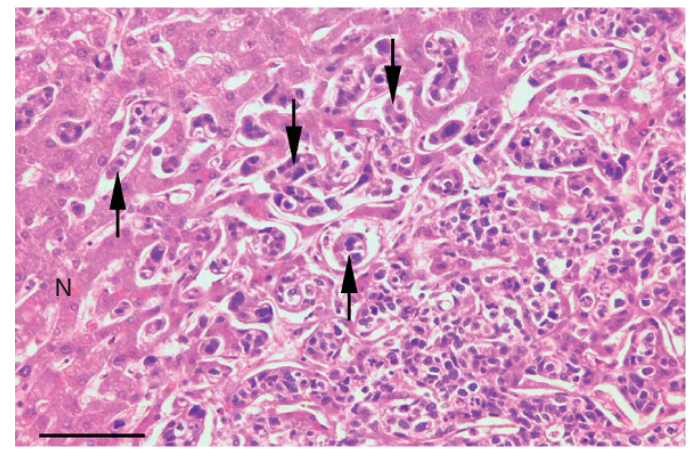

Figure 5. H\&E image of the sinusoidal histopathological growth pattern. Arrowheads indicate tumour cell emboli present within the lumen of liver sinusoidal vessels. N, normal liver parenchyma. Scale bar $=100 \mu \mathrm{m}$.
We then repeated the overall survival analysis in order to determine whether using different cutoffs to define the predominant HGP would affect the relationship between the HGP and overall survival. Owing to the low numbers of patients presenting with a predominantly pushing HGP (only 3\% of patients when using a cutoff of $>50 \%$ ), we limited our analysis to a comparison of overall survival between the replacement HGP patients versus the desmoplastic HGP patients. Cut points of $>50 \%,>70 \%,>80 \%,>90 \%$ or $100 \%$ were used to define whether a tumour had a predominant replacement HGP or a predominant desmoplastic HGP (Table 7). The first thing that emerges from this analysis is that, predictably, the use of higher cutoffs incrementally reduces the number of patients eligible for inclusion in the analysis. For example, while 360 patients are eligible using a cut point of $>50 \%$, this drops to 291 eligible patients using a cut point of $>70 \%$ and drops to 134 patients using a cut point of $100 \%$. However, overall survival was significantly superior in the desmoplastic HGP subgroup, as compared with the replacement HGP subgroup, at all cutoffs utilised (both by Kaplan-Meier analysis and in multivariate analysis, Table 7).

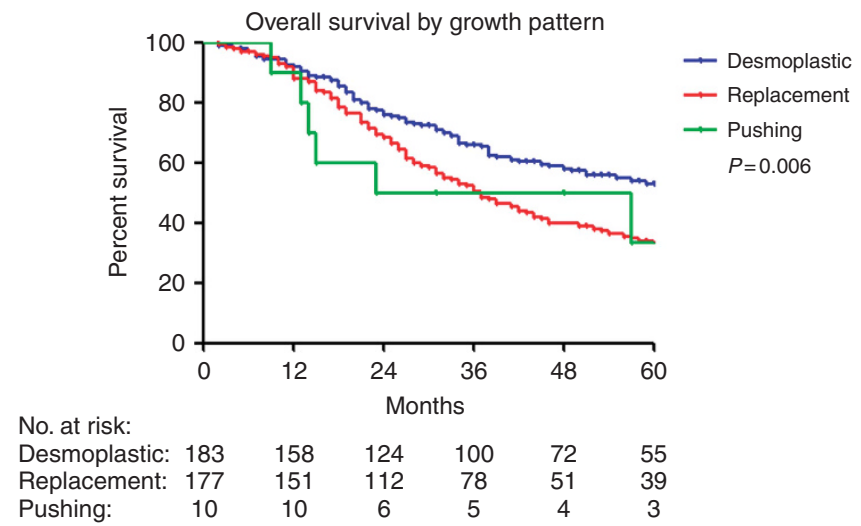

Figure 7. Clinical validation of the guidelines. Kaplan-Meier curves depicting overall survival of patients with colorectal liver metastases, stratified by predominant ( $>50 \%$ ) HGP ( $n=370$ patients).
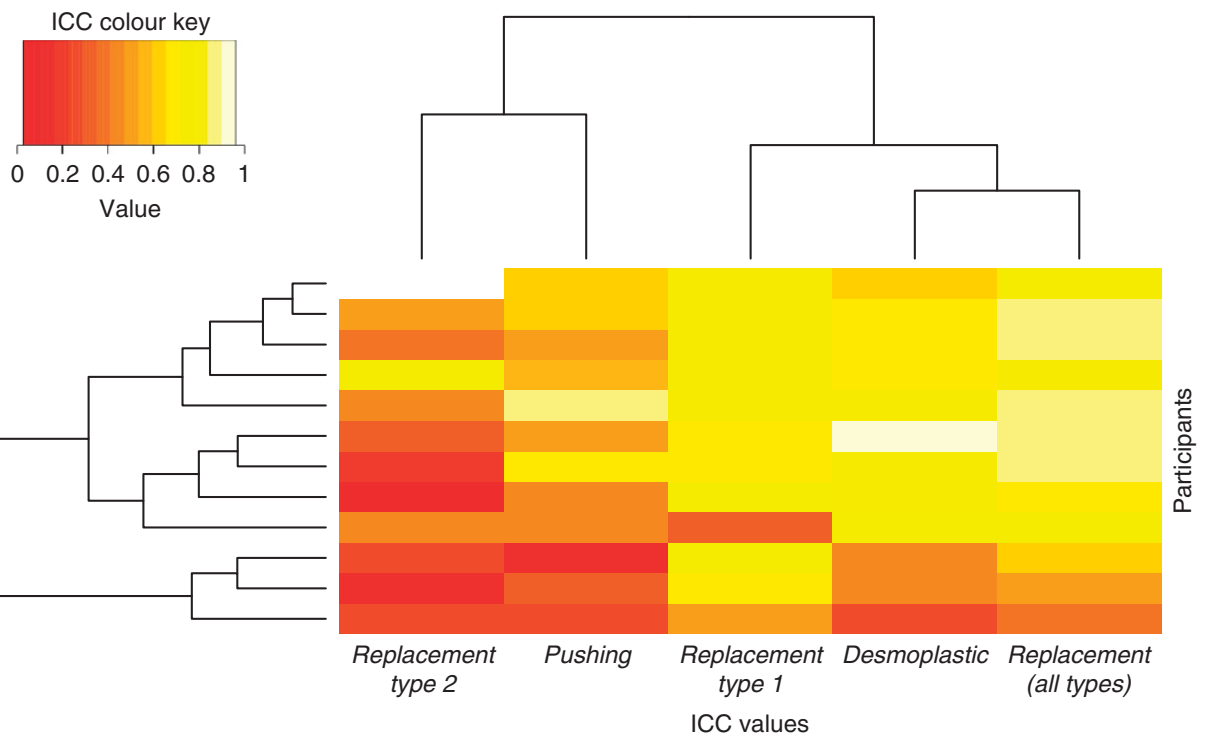

Figure 6. Analytical validation of the guidelines. Heat map of the unsupervised hierarchical clustering of the colour-coded mean intraclass correlation coefficients of each growth pattern for all observers ( $n=12$ observers). 
Table 5. Clinicopathological characteristics in the final cohort used for clinical validation, excluding 4 patients with a 'mixed type' HGP

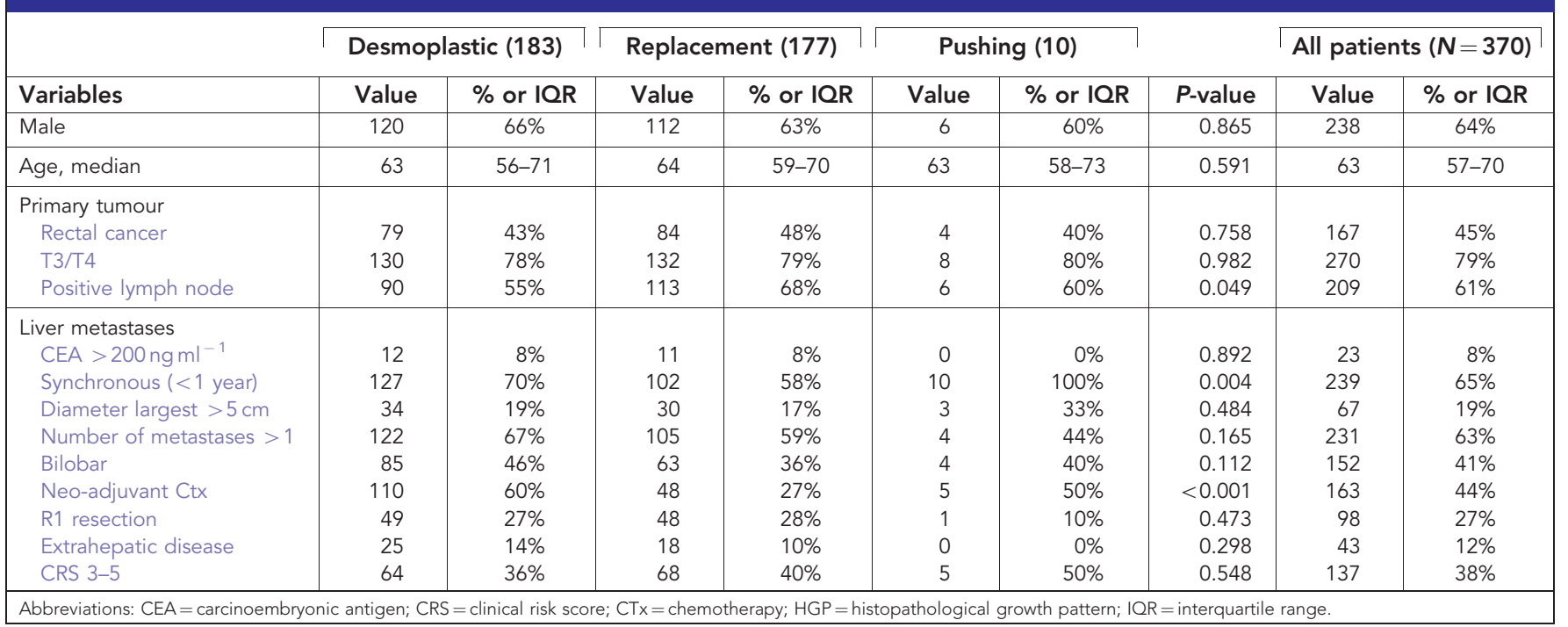

Table 6. Univariate and multivariate analysis (overall survival)

\begin{tabular}{|c|c|c|c|c|c|}
\hline Univariate & $\mathrm{HR}(95 \% \mathrm{Cl})$ & $P$-value & Multivariate & HR (95\% Cl) & $P$-value \\
\hline Positive lymph node & $1.267(0.947-1.697)$ & 0.111 & Neo-adjuvant CTx & $1.224(0.893-1.678)$ & 0.208 \\
\hline Synchronous ( $<1$ year) & $1.162(0.878-1.537)$ & 0.294 & CRS 3-5 (Fong) & $1.971(1.466-2.650)$ & $<0.001$ \\
\hline CRS 3-5 (Fong) & $2.005(1.521-2.642)$ & $<0.001$ & Replacement HGP & $1.729(1.283-2.332)$ & $<0.001$ \\
\hline Desmoplastic HGP & 1 & & Pushing HGP & $1.269(0.553-2.908)$ & 0.574 \\
\hline Replacement HGP & $1.556(1.181-2.050)$ & 0.019 & & & \\
\hline
\end{tabular}

Table 7. Comparison of overall survival in patients with a predominant replacement HGP versus patients with a predominant desmoplastic HGP (using different \%HGP cutoffs to define the predominant HGP)

\begin{tabular}{|l|c|c|c|c|c|}
\hline $\begin{array}{l}\text { HGP } \\
\text { cutoff }\end{array}$ & $\begin{array}{c}\text { Total pts in the } \\
\text { analysis }\end{array}$ & $\begin{array}{c}\text { No. of pts } \\
\text { predominant } \\
\text { replacement }\end{array}$ & $\begin{array}{c}\text { No. of pts } \\
\text { predominant } \\
\text { desmoplastic }\end{array}$ & $\begin{array}{c}\text { Kaplan-Meier } \\
\boldsymbol{P} \text {-value }\end{array}$ & Hazard ratio from multivariate analysis \\
\hline$>50 \%$ & 360 & 177 & 183 & $P=0.001$ & $1.79(95 \% \mathrm{Cl}: 1.31-2.43) P<0.001$ \\
\hline$>70 \%$ & 291 & 139 & 152 & $P=0.009$ & $1.72(95 \% \mathrm{Cl}: 1.21-2.46) P=0.003$ \\
\hline$>80 \%$ & 266 & 124 & 142 & $P=0.005$ & $1.88(95 \% \mathrm{Cl}: 1.29-2.73) P=0.001$ \\
\hline$>90 \%$ & 233 & 108 & 125 & $P=0.003$ & $2.13(95 \% \mathrm{Cl}: 1.41-3.20) P<0.001$ \\
\hline $100 \%$ & 134 & 51 & 83 & $P<0.001$ & $2.89(95 \% \mathrm{Cl}: 1.66-5.02) P<0.001$ \\
\hline
\end{tabular}

\section{DISCUSSION}

The current manuscript describes the first guidelines for scoring the HGPs of liver metastases, based on an international consensus among experts in the field. Furthermore, we show that, by applying these guidelines after adequate training, a reproducible assessment of the HGPs in human specimens of liver metastases is possible. In addition, it is demonstrated that the HGPs scored according to these guidelines determine overall survival in patients with liver metastases of CRC.

Although the scoring can be performed reliably even by nonspecialists and is reproducible between individuals as shown in our analytical validation study, some limitations were noted, among them the difficulty of distinguishing the pushing HGP from the type 2 replacement HGP. This distinction is important, given that the interaction of the cancer cells with the liver is completely different in the two HGPs. For example, the pushing growth pattern relies on sprouting angiogenesis for its vasculature while the replacement growth pattern co-opts the sinusoidal blood vessels of the liver (Vermeulen et al, 2001; Van den Eynden et al, 2013; Frentzas et al, 2016).

In the current study, the HGPs scored according to the proposed guidelines predict outcome: patients with a predominant desmoplastic HGP have a significant overall survival advantage as compared with patients with a predominant replacement HGP or predominant pushing HGP. This is clearly in accordance with the studies in Table 1 that have addressed the prognostic value of the 
HGPs (Okano et al, 2000; Lunevicius et al, 2001; Nystrom et al, 2012; Van den Eynden et al, 2012; Nielsen et al, 2014; Pinheiro et al, 2014; Eefsen et al, 2015; Frentzas et al, 2016). However, there are some discrepancies in the reported impact of the replacement HGP and the pushing HGP on outcome (for details, see Table 1). These discrepancies may arise due to differences in the patient cohorts examined and/or due to differences in the way the HGPs were scored in different studies. For instance, the percentage of patients who received systemic treatment prior to the resection of liver metastases may influence the results, as suggested by the evidence that preoperative therapy may cause a conversion from a desmoplastic HGP to a replacement HGP (Mentha et al, 2009; Frentzas et al, 2016). With regards to the methods in which the HGPs were scored, the cutoffs for classifying a metastasis as having a predominant HGP differ between different studies, ranging from $50 \%$ to $80 \%$ of the total length of the interface. Also, the distinction between the pushing HGP and the type 2 replacement HGP was not well defined in previous studies. Furthermore, all of these factors have impacted on the variability documented in the relative proportions of the different HGPs. Indeed, as an example, the pushing HGP was reported as the predominant HGP in $\sim 7 \%$ of all samples in the study by Frentzas et al (2016) and in $\sim 3 \%$ of all samples in the survival study in this manuscript. However, in other studies, this fraction was as high as 16\% (Van den Eynden et al, 2012), 33\% (Nielsen et al, 2014), 34\% (Eefsen et al, 2015) and even $50 \%$ (Nystrom et al, 2012). These issues highlight the need for standardised and uniform criteria for HGP classification - a major aim of the present guidelines.

Although we show here that scoring the HGPs of liver metastases is reproducible, in order to use the HGPs as a biomarker for treatment decisions it will be necessary to develop accurate non-invasive surrogate markers for this histopathological parameter. For example, medical imaging of the liver, such as MRI or CT scans that are performed routinely in clinical practice, might eventually be utilised as a surrogate method to determine the HGPs of liver metastasis. We note that Semelka et al (2000) found that the presence of transient perilesional enhancement on the MRI image is correlated with the presence of a desmoplastic reaction around the rim of liver metastases. However, transient perilesional enhancement was not present on the MRI image for liver metastases that lacked a desmoplastic reaction (Semelka et al, 2000). It is therefore possible that transient perilesional enhancement is a potential surrogate marker that distinguishes desmoplastic HGP liver metastases from pushing/replacement HGP liver metastases on MRI scans of the liver. However, a prospective imaging study performed in a large series of chemotherapy-naive patients is necessary in order to validate whether this imaging feature (or other imaging features) can be successfully used to predict the HGPs of liver metastasis. A study of this sort is currently ongoing in Sweden (Hanna Nyström, personal communication). Furthermore, by longitudinal assessment of the HGPs, through repeated imaging of the same patients, it will also be possible to appreciate the dynamic nature of the HGPs. This is relevant because several studies suggest that the HGP of a tumour can change. For instance, there is evidence that, after systemic treatment with an antiangiogenic agent, liver metastases can switch from an angiogenic desmoplastic HGP to the non-angiogenic replacement HGP (Mentha et al, 2009; Frentzas et al, 2016). Furthermore, a change from an angiogenic growth pattern to a non-angiogenic growth pattern upon treatment with antiangiogenic therapy has also been reported in preclinical models of hepatocellular carcinoma (Kuczynski et al, 2016), lung metastasis (Bridgeman et al, 2017), glioblastoma (GBM; Rubenstein et al, 2000) and brain metastasis (Leenders et al, 2004).

There is currently limited understanding of the biological mechanisms that underlie the different HGPs. Moreover, it is unclear why some tumours elicit a desmoplastic and angiogenic response while others grow in a non-angiogenic manner and adopt the replacement growth pattern. HGPs are, however, a broader phenomenon not restricted to liver metastases and have also been described in primary lung cancer (Pezzella et al, 1997) and lung metastases (Pezzella et al, 1996; Szabo et al, 2015; Bridgeman et al, 2017), primary brain tumours and brain metastases (Sakariassen et al, 2006; Bugyik et al, 2011; Berghoff et al, 2013; Valiente et al, 2014), lymph node metastases (Naresh et al, 2001; Vermeulen et al, 2002; Jeong et al, 2015) and skin metastases (Colpaert et al, 2003). Common biological themes, based on the interplay between cancer cells and the organ microenvironment, may thus be responsible for the HGPs in different organs.

One working hypothesis to explain the biology of the different HGPs of liver metastases is that these HGPs recapitulate distinct reaction patterns of the liver to injury. Two reaction patterns to liver injury are known, liver fibrosis and liver regeneration, and they are characterised by specific cytokine profiles (Ding et al, 2014). Fibrosis in the desmoplastic HGP may be mediated by the same biological mechanisms that drive liver fibrosis in response to injury. One hallmark of liver fibrosis is ductular reaction, which is a proliferation of activated cholangiocytes that form small nonfunctional bile ductular structures (Schuppan and Kim, 2013). Indeed, ductular reaction is also present in the fibrotic rim of desmoplastic liver metastases (see Figure 2E). The replacement HGP, on the other hand, resembles liver regeneration, as cancer cells replace hepatocytes akin to the way that new hepatocytes replace older hepatocytes during liver regeneration (Oertel et al, 2006; Dezso et al, 2012). Soluble angiocrine factors (which are secreted by endothelial cells in sinusoidal blood vessels) have a major role during liver fibrosis, liver regeneration and in liver development (Matsumoto et al, 2001; Ding et al, 2010; Si-Tayeb et al, 2010; Ding et al, 2014). However, the role of these angiocrine factors in liver metastasis growth patterns is yet to be elucidated and is currently under investigation.

Desmoplastic and pushing growth pattern tumours are associated with new vessel formation (via angiogenesis), while replacement growth pattern tumours are not dependent on angiogenesis and co-opt preexisting sinusoidal blood vessels instead (Vermeulen et al, 2001; Stessels et al, 2004; Van den Eynden et al, 2013; Frentzas et al, 2016). Therefore, another significant question is: how are these different vascularisation mechanisms co-ordinated in the liver? Although this is yet to be elucidated, insight may come from studies performed in GBM. Similar to the liver metastasis scenario, GBM tumours displaying either an angiogenic growth pattern or a vessel co-opting growth pattern have also been described (Sakariassen et al, 2006). Sakariassen et al (2006) used PDX models of GBM to study what drives these different growth patterns in the brain. They showed that, while angiogenic GBMs and vessel co-opting GBMs are genetically similar (as determined by array CGH), marked differences in gene expression occur between these growth patterns. Notably, vessel co-opting GBMs had upregulated expression of genes associated with foetal development and cell motility when compared with angiogenic tumours. In contrast, angiogenic GBMs showed higher expression of angiogenic regulators, such as VEGF and angiopoetin-2, when compared with vessel co-opting tumours (Sakariassen et al, 2006). These data suggest that tumour growth patterns are associated with differences in tumour gene expression, which may be drivers of the growth pattern. We are currently undertaking a transcriptomic analysis of human liver metastases to determine whether similar differences in gene expression can be found between liver metastases adopting different growth patterns (Van Laere et al, manuscript in preparation).

Other studies, performed using preclinical brain metastasis models, have shown that cancer cells adhere to preexisting brain vessels during vessel co-option in the brain and that this may be 
mediated by distinct cell adhesion molecules expressed by cancer cells, such as $\beta 1$-integrins or L1CAM (Dome et al, 2003; Carbonell et al, 2009; Bugyik et al, 2011; Valiente et al, 2014). In the replacement growth pattern of liver metastases, our histopathological observations suggest that cancer cells also adhere to the sinusoidal blood vessels. Moreover, others have reported that 'adhesive co-option' of sinusoidal blood vessels by cancer cells, mediated by integrins, has a role in liver metastasis (Kemperman et al, 1997). Taken together, these data suggest that the propensity for cancer cells to adopt a specific growth pattern may also involve important changes in the ability of cancer cells to adhere to preexisting blood vessels.

In addition, the progression of cancer along preexisting basement membranes (as observed in the replacement growth pattern) clearly resembles what pathologists recognise as in situ carcinoma, a presentation in which cancer cells respect the existing structure of the host organ. Although this is typically a feature that has been described to occur in primary tumours (i.e., occurring prior to invasion and subsequent metastasis), reversion of metastatic cancer to this in situ phase has indeed been documented in other sites, for instance, in lymph node metastases (Barsky et al, 1997). Therefore, the adoption of the replacement growth pattern may also represent a form of reversion to in situ tumour growth.

We find that, while approximately one-third of patients present with a 'pure' growth pattern (i.e., 100\% desmoplastic, $100 \%$ pushing or $100 \%$ replacement HGP), approximately two-thirds of patients present with a mixed growth pattern. Unfortunately, the biological basis for this heterogeneity of growth pattern within the same patient remains unclear. However, future studies aimed at addressing the molecular mechanisms that underlie the growth patterns should provide insight as to the basis for this heterogeneity. As for the practical significance of a mixed growth pattern, it is apparent that, even when a mixture of growth patterns is present, the predominant growth pattern can still have a significant effect on patient outcome. For example, around twothirds of the patients included in our overall survival analysis (using the $>50 \%$ cut point) presented with a mixture of growth patterns, and yet the predominant growth pattern still had a statistically significant effect on overall survival. There is also evidence that treatment with standard therapies can alter the growth pattern of liver metastases from desmoplastic to replacement (Mentha et al, 2009; Frentzas et al, 2016). It is therefore possible that, in some cases, liver metastases with a mixed growth pattern represent those tumours that are in a state of transition from one growth pattern to another. If it is the case that standard therapies can indeed drive a shift in growth pattern from a good prognosis pattern (i.e., desmoplastic) to a bad prognosis pattern (i.e., replacement), then it may be necessary to derive therapeutic strategies that can either prevent or combat this adverse transition.

In conclusion, we provide clear and reproducible guidelines for scoring the HGPs of liver metastasis. The HGPs have a prognostic and predictive value for patients with liver metastatic CRC as demonstrated here and in other retrospective studies (Okano et al, 2000; Lunevicius et al, 2001; Nystrom et al, 2012; Van den Eynden et al, 2012; Nielsen et al, 2014; Pinheiro et al, 2014; Eefsen et al, 2015; Frentzas et al, 2016). Prospective studies based on large cohorts of patients, and preferably linked to clinical trials, are now needed to confirm the clinical value of the HGPs and to assess the value of medical imaging, or circulating molecular markers, as potential surrogate biomarkers for the HGPs. Moreover, further studies are now warranted to understand the molecular mechanisms that underlie the HGPs, because these may eventually lead to HGP-specific treatment strategies for liver metastases. This could pave the way for an improved selection strategy for the type of systemic treatment before and/or after liver surgery and for personalised risk-adapted follow-up strategies.

\section{CONFLICT OF INTEREST}

The authors declare no conflict of interest.

\section{REFERENCES}

Allison KH, Fligner CL, Parks WT (2004) Radiographically occult, diffuse intrasinusoidal hepatic metastases from primary breast carcinomas: a clinicopathologic study of 3 autopsy cases. Arch Pathol Lab Med 128(12): 1418-1423.

Barsky SH, Doberneck SA, Sternlicht MD, Grossman DA, Love SM (1997) 'Revertant' DCIS in human axillary breast carcinoma metastases. J Pathol 183(2): 188-194.

Berghoff AS, Rajky O, Winkler F, Bartsch R, Furtner J, Hainfellner JA, Goodman SL, Weller M, Schittenhelm J, Preusser M (2013) Invasion patterns in brain metastases of solid cancers. Neuro Oncol 15(12): $1664-1672$.

Bridgeman VL, Vermeulen PB, Foo S, Bilecz A, Daley F, Kostaras E, Nathan MR, Wan E, Frentzas S, Schweiger T, Hegedus B, Hoetzenecker K, Renyi-Vamos F, Kuczynski EA, Vasudev NS, Larkin J, Gore M, Dvorak HF, Paku S, Kerbel RS, Dome B, Reynolds AR (2017) Vessel cooption is common in human lung metastases and mediates resistance to anti-angiogenic therapy in preclinical lung metastasis models. J Pathol 241(3): 362-374.

Bugyik E, Dezso K, Reiniger L, Laszlo V, Tovari J, Timar J, Nagy P, Klepetko W, Dome B, Paku S (2011) Lack of angiogenesis in experimental brain metastases. J Neuropathol Exp Neurol 70(11): 979-991.

Carbonell WS, Ansorge O, Sibson N, Muschel R (2009) The vascular basement membrane as 'soil' in brain metastasis. PLoS One 4(6): e5857.

Colpaert CG, Vermeulen PB, Van Beest P, Soubry A, Goovaerts G, Dirix LY, Harris AL, Van Marck EA (2003) Cutaneous breast cancer deposits show distinct growth patterns with different degrees of angiogenesis, hypoxia and fibrin deposition. Histopathology 42(6): 530-540.

Dezso K, Papp V, Bugyik E, Hegyesi H, Safrany G, Bodor C, Nagy P, Paku S (2012) Structural analysis of oval-cell-mediated liver regeneration in rats. Hepatology 56(4): 1457-1467.

Ding BS, Cao Z, Lis R, Nolan DJ, Guo P, Simons M, Penfold ME, Shido K, Rabbany SY, Rafii S (2014) Divergent angiocrine signals from vascular niche balance liver regeneration and fibrosis. Nature 505(7481): 97-102.

Ding BS, Nolan DJ, Butler JM, James D, Babazadeh AO, Rosenwaks Z, Mittal V, Kobayashi H, Shido K, Lyden D, Sato TN, Rabbany SY, Rafii S (2010) Inductive angiocrine signals from sinusoidal endothelium are required for liver regeneration. Nature 468(7321): 310-315.

Disibio G, French SW (2008) Metastatic patterns of cancers: results from a large autopsy study. Arch Pathol Lab Med 132(6): 931-939.

Dome B, Timar J, Paku S (2003) A novel concept of glomeruloid body formation in experimental cerebral metastases. J Neuropathol Exp Neurol 62(6): 655-661.

Eefsen RL, Engelholm L, Alpizar-Alpizar W, Van den Eynden GG, Vermeulen PB, Christensen IJ, Laerum OD, Rolff HC, Hoyer-Hansen G, Vainer B, Osterlind K, Illemann M (2015) Inflammation and uPARexpression in colorectal liver metastases in relation to growth pattern and neo-adjuvant therapy. Cancer Microenviron 8(2): 93-100.

Eefsen RL, Van den Eynden GG, Hoyer-Hansen G, Brodt P, Laerum OD, Vermeulen PB, Christensen IJ, Wettergren A, Federspiel B, Willemoe GL, Vainer B, Osterlind K, Illemann M (2012) Histopathological growth pattern, proteolysis and angiogenesis in chemonaive patients resected for multiple colorectal liver metastases. J Oncol 2012: 907971.

Elias H, Bierring F, Grunnet I (1964) Cellular changes in the vicinity of metastatic carcinoma, observed by light and electron microscopy. Oncology 18: 210-224.

Elias H. SJC, Bouldin RF (1962) Reaction of the normal liver parenchyma to metastatic carcinoma. Acta Hepatosplenol 9(6): 357-386.

Fong Y, Fortner J, Sun RL, Brennan MF, Blumgart LH (1999) Clinical score for predicting recurrence after hepatic resection for metastatic colorectal cancer: analysis of 1001 consecutive cases. Ann Surg 230(3): 309-318 discussion 318-321.

Frentzas S, Simoneau E, Bridgeman VL, Vermeulen PB, Foo S, Kostaras E, Nathan MR, Wotherspoon A, Gao ZH, Shi Y, Van den Eynden G, Daley F, Peckitt C, Tan X, Salman A, Lazaris A, Gazinska P, Berg TJ, Eltahir Z, Ritsma L, van Rheenen J, Khashper A, Brown G, Nystrom H, Sund M, 
Van Laere S, Loyer E, Dirix L, Cunningham D, Metrakos P, Reynolds AR (2016) Vessel co-option mediates resistance to anti-angiogenic therapy in liver metastases. Nat Med 22(11): 1294-1302.

Hamperl H (1956) Die morphologie der tumoren. Lehrbuch Der Allgemeinen Pathologie Und Der Pathologischen Anatomie 6(3): 243-244.

Illemann M, Bird N, Majeed A, Laerum OD, Lund LR, Dano K, Nielsen BS (2009) Two distinct expression patterns of urokinase, urokinase receptor and plasminogen activator inhibitor-1 in colon cancer liver metastases. Int J Cancer 124(8): 1860-1870.

Jass JR, Love SB, Northover JM (1987) A new prognostic classification of rectal cancer. Lancet 1(8545): 1303-1306.

Jeong HS, Jones D, Liao S, Wattson DA, Cui CH, Duda DG, Willett CG, Jain RK, Padera TP (2015) Investigation of the lack of angiogenesis in the formation of lymph node metastases. J Natl Cancer Inst 107(9).

Kemperman H, Wijnands YM, Roos E (1997) AlphaV Integrins on HT-29 colon carcinoma cells: adhesion to fibronectin is mediated solely by small amounts of alphaVbeta6, and alphaVbeta5 is codistributed with actin fibers. Exp Cell Res 234(1): 156-164.

Kuczynski EA, Yin M, Bar-Zion A, Lee CR, Butz H, Man S, Daley F, Vermeulen PB, Yousef GM, Foster FS, Reynolds AR, Kerbel RS (2016) Co-option of liver vessels and not sprouting angiogenesis drives acquired sorafenib resistance in hepatocellular carcinoma. J Natl Cancer Inst 108(8).

Leenders WP, Kusters B, Verrijp K, Maass C, Wesseling P, Heerschap A, Ruiter D, Ryan A, de Waal R (2004) Antiangiogenic therapy of cerebral melanoma metastases results in sustained tumor progression via vessel cooption. Clin Cancer Res 10(18 Pt 1): 6222-6230.

Lunevicius R, Nakanishi H, Ito S, Kozaki K, Kato T, Tatematsu M, Yasui K (2001) Clinicopathological significance of fibrotic capsule formation around liver metastasis from colorectal cancer. J Cancer Res Clin Oncol 127(3): 193-199.

Masson P (1923) Les tumeurs. Traité De Pathologie Et Thérapie Appliquées 27(2): 572-574.

Matsumoto K, Yoshitomi H, Rossant J, Zaret KS (2001) Liver organogenesis promoted by endothelial cells prior to vascular function. Science 294(5542): 559-563.

Mentha G, Terraz S, Morel P, Andres A, Giostra E, Roth A, Rubbia-Brandt L, Majno P (2009) Dangerous halo after neoadjuvant chemotherapy and two-step hepatectomy for colorectal liver metastases. Br J Surg 96(1): 95-103.

Naresh KN, Nerurkar AY, Borges AM (2001) Angiogenesis is redundant for tumour growth in lymph node metastases. Histopathology 38(5): 466-470.

Nielsen K, Rolff HC, Eefsen RL, Vainer B (2014) The morphological growth patterns of colorectal liver metastases are prognostic for overall survival. Mod Pathol 27(12): 1641-1648.

Nystrom H, Naredi P, Berglund A, Palmqvist R, Tavelin B, Sund M (2012) Liver-metastatic potential of colorectal cancer is related to the stromal composition of the tumour. Anticancer Res 32(12): 5183-5191.

Oertel M, Menthena A, Dabeva MD, Shafritz DA (2006) Cell competition leads to a high level of normal liver reconstitution by transplanted fetal liver stem/progenitor cells. Gastroenterology 130(2): 507-520, quiz 590.

Okano K, Yamamoto J, Kosuge T, Yamamoto S, Sakamoto M, Nakanishi Y, Hirohashi S (2000) Fibrous pseudocapsule of metastatic liver tumors from colorectal carcinoma. Clinicopathologic study of 152 first resection cases. Cancer 89(2): 267-275.

Pezzella F, Di Bacco A, Andreola S, Nicholson AG, Pastorino U, Harris AL (1996) Angiogenesis in primary lung cancer and lung secondaries. Eur J Cancer 32A(14): 2494-2500.

Pezzella F, Pastorino U, Tagliabue E, Andreola S, Sozzi G, Gasparini G, Menard S, Gatter KC, Harris AL, Fox S, Buyse M, Pilotti S, Pierotti M, Rilke F (1997) Non-small-cell lung carcinoma tumor growth without morphological evidence of neo-angiogenesis. Am J Pathol 151(5): 1417-1423.

Pinheiro RS, Herman P, Lupinacci RM, Lai Q, Mello ES, Coelho FF, Perini MV, Pugliese V, Andraus W, Cecconello I, D’Albuquerque LC (2014) Tumor growth pattern as predictor of colorectal liver metastasis recurrence. Am J Surg 207(4): 493-498.

Poston GJ (2008) Staging of advanced colorectal cancer. Surg Oncol Clin N Am 17(3): 503-517viii.

Poston GJ, Figueras J, Giuliante F, Nuzzo G, Sobrero AF, Gigot JF, Nordlinger B, Adam R, Gruenberger T, Choti MA, Bilchik AJ, Van Cutsem EJ, Chiang JM, D'Angelica MI (2008) Urgent need for a new staging system in advanced colorectal cancer. J Clin Oncol 26(29): 48284833.

Rajaganeshan R, Prasad R, Guillou PJ, Chalmers CR, Scott N, Sarkar R, Poston G, Jayne DG (2007) The influence of invasive growth pattern and microvessel density on prognosis in colorectal cancer and colorectal liver metastases. Br J Cancer 96(7): 1112-1117.

Rubenstein JL, Kim J, Ozawa T, Zhang M, Westphal M, Deen DF, Shuman MA (2000) Anti-VEGF antibody treatment of glioblastoma prolongs survival but results in increased vascular cooption. Neoplasia 2(4): 306-314.

Sakariassen PO, Prestegarden L, Wang J, Skaftnesmo KO, Mahesparan R, Molthoff C, Sminia P, Sundlisaeter E, Misra A, Tysnes BB, Chekenya M, Peters H, Lende G, Kalland KH, Oyan AM, Petersen K, Jonassen I, van der Kogel A, Feuerstein BG, Terzis AJ, Bjerkvig R, Enger PO (2006) Angiogenesis-independent tumor growth mediated by stem-like cancer cells. Proc Natl Acad Sci USA 103(44): 16466-16471.

Schmoll HJ, Van Cutsem E, Stein A, Valentini V, Glimelius B, Haustermans K, Nordlinger B, van de Velde CJ, Balmana J, Regula J, Nagtegaal ID, Beets-Tan RG, Arnold D, Ciardiello F, Hoff P, Kerr D, Kohne CH, Labianca R, Price T, Scheithauer W, Sobrero A, Tabernero J, Aderka D, Barroso S, Bodoky G, Douillard JY, El Ghazaly H, Gallardo J, Garin A, Glynne-Jones R, Jordan K, Meshcheryakov A, Papamichail D, Pfeiffer P, Souglakos I, Turhal S, Cervantes A (2012) ESMO Consensus Guidelines for management of patients with colon and rectal cancer. a personalized approach to clinical decision making. Ann Oncol 23(10): 2479-2516.

Schuppan D, Kim YO (2013) Evolving therapies for liver fibrosis. J Clin Invest 123(5): 1887-1901.

Semelka RC, Hussain SM, Marcos HB, Woosley JT (2000) Perilesional enhancement of hepatic metastases: correlation between MR imaging and histopathologic findings-initial observations. Radiology 215(1): 89-94.

Si-Tayeb K, Lemaigre FP, Duncan SA (2010) Organogenesis and development of the liver. Dev Cell 18(2): 175-189.

Simone C, Murphy M, Shifrin R, Zuluaga Toro T, Reisman D (2012) Rapid liver enlargement and hepatic failure secondary to radiographic occult tumor invasion: two case reports and review of the literature. J Med Case Rep 6: 402 .

Stessels F, Van den Eynden G, Van der Auwera I, Salgado R, Van den Heuvel E, Harris AL, Jackson DG, Colpaert CG, van Marck EA, Dirix LY, Vermeulen PB (2004) Breast adenocarcinoma liver metastases, in contrast to colorectal cancer liver metastases, display a non-angiogenic growth pattern that preserves the stroma and lacks hypoxia. Br J Cancer 90(7): 1429-1436.

Szabo V, Bugyik E, Dezso K, Ecker N, Nagy P, Timar J, Tovari J, Laszlo V, Bridgeman VL, Wan E, Frentzas S, Vermeulen PB, Reynolds AR, Dome B, Paku S (2015) Mechanism of tumour vascularization in experimental lung metastases. J Pathol 235(3): 384-396.

Valiente M, Obenauf AC, Jin X, Chen Q, Zhang XH, Lee DJ, Chaft JE, Kris MG, Huse JT, Brogi E, Massague J (2014) Serpins promote cancer cell survival and vascular co-option in brain metastasis. Cell 156(5): 1002-1016.

Van den Eynden GG, Bird NC, Majeed AW, Van Laere S, Dirix LY, Vermeulen PB (2012) The histological growth pattern of colorectal cancer liver metastases has prognostic value. Clin Exp Metastasis 29(6): 541-549.

Van den Eynden GG, Majeed AW, Illemann M, Vermeulen PB, Bird NC, Hoyer-Hansen G, Eefsen RL, Reynolds AR, Brodt P (2013) The multifaceted role of the microenvironment in liver metastasis: biology and clinical implications. Cancer Res 73(7): 2031-2043.

Vermeulen PB, Colpaert C, Salgado R, Royers R, Hellemans H, Van Den Heuvel E, Goovaerts G, Dirix LY, Van Marck E (2001) Liver metastases from colorectal adenocarcinomas grow in three patterns with different angiogenesis and desmoplasia. J Pathol 195(3): 336-342.

Vermeulen PB, Sardari Nia P, Colpaert C, Dirix LY, Van Marck E (2002) Lack of angiogenesis in lymph node metastases of carcinomas is growth pattern-dependent. Histopathology 40(1): 105-107.

This work is published under the standard license to publish agreement. After 12 months the work will become freely available and the license terms will switch to a Creative Commons AttributionNonCommercial-Share Alike 4.0 Unported License. 